\title{
Approaching Country Sanctuaries
}

Although rising poleis in the Hellenistic period in Asia Minor frequently invested in established sanctuaries that were located far away from their urban centers, a line of inquiry to approach this phenomenon has yet to be developed. Investigations of such country sanctuaries until now have largely focused on questions of cultural identity or local autonomy in the face of shifting political landscapes. Yet the factor of human geography in this relationship is seldom problematized, even though long an object of study for the Archaic Greek world. A gap thus remains concerning country sanctuaries in Hellenistic Asia Minor and how they should be interpreted with regard to evolving urban systems. The aim of this chapter is to produce a framework of analysis that takes into account the complexities of the situation. Prior research on the phenomenon of 'extra-urban' sanctuaries in Archaic Greece and relevant studies in Asia Minor are taken as point of departure, raising significant aspects that need to be addressed. To understand the dynamics, however, theories drawn from other disciplines - spatial memory, 'rational rituals,, ${ }^{1}$ network theory, and regional identity - are introduced that will help illuminate important factors regarding matters of motivation, agency, and impact behind the tightening relations between city and sanctuary. Taken together, the previous research, theories, and alternative models, inform the main domains of investigation defined in the framework of analysis, discussed in the final section of this chapter.

Monumental shrines in rural areas are lightening rods for discussions on the conceptualization of the city and its countryside in the ancient Greek world, and of cultural identity and degrees of autonomy in Asia Minor. The first section of this chapter reviews some of the most pivotal theories and the debates they have sparked regarding the interpretations of established sanctuaries in the countryside that have led to this present research.

1 Chwe (2001). 


\subsection{Extra-Urban' Sanctuaries in the Greek World}

The urban-rural axis has become a central component of archaeological discourse on the ancient Greek city. Drawing on the Christaller's Central Place Theory, the Greek polis is perceived to be divided into concentric zones radiating out from the town center, or asty, and its countryside, the chora. ${ }^{2}$ Rural sanctuaries that were once considered remote or isolated in the landscape are now generally seen in the context of the chora, i.e. still within the sphere of urban space, but at points near or far from the nucleus, and are classified accordingly. Coinciding with the core-periphery model is the interpretation of sanctuaries near political borders as frontier sanctuaries, a view that especially gained momentum after the appearance of François de Polignac's seminal work La naissance de la cité grecque in 1984. His 'bi-polar model', which depicts the Greek polis as typically consisting of an urban center with a major 'extra-urban' sanctuary at the border, brought attention to the role of frontier sanctuaries, so much so that 'extra-urban' and 'frontier' are often interchanged as qualifiers. ${ }^{3}$ De Polignac's work is both influential and problematic, drawing criticism for its monolithic view of the Greek city and for the underlying coreperiphery and urban-rural biases. Later alternatives for interpreting grand country sanctuaries turn instead to models of continuity and network theory; these will be explored in the last part of this section.

\section{Sanctuary}

Studies on the ancient Greek cityscape long focused on the formal classification of architectural remains and town planning, e.g. tracing Hippodamian influences, ${ }^{4}$ with shrines in rural settings being typically treated in splendid isolation. ${ }^{5}$ In the 1970 s this began to change as New Archaeology with its environmental bias and Braudel's monumental work on the role of landscape

2 Christaller (1933), schematized in Hölscher (2013), 48, Abb.1.

3 E.g. Voyatzis (1999), 151, drawing from de Polignac (1995), 33-41.

4 See overview in Osborne (1987), 13-26. An important exception is Numa Fustel de Coulanges, whose epic work addressed the city-state, rather than the town, with religion as key to its functioning, de Coulanges (1864); Finley (1977). Also, Louis Robert was keenly aware of role of landscape and climate at the sites he visited in Turkey in the 1930s, evidenced for example in his extensive notes taken en route to the sanctuary of Sinuri; Virgilio (2010). E.g. Castagnoli (1971) and Ward-Perkins (1974) on orthogonal planning.

5 On sanctuaries, Berve and Gruben (1961), and Tomlinson (1976). Scully (1962) is an important exception with its focus on landscape features; Thompson (1963) rejected his thesis due to lack of correlates in classical literature. Also Stillwell (1954) and Lehmann (1954) who took aesthetic criteria into account in temple location, and the ground-breaking Semple (1927) on templed promontories in connection with seafaring. The natural setting of sanctuaries 
in Mediterranean history made inroads on classical archaeology, especially among Anglo-Saxon scholars. ${ }^{6}$ From this time onwards, systematic investigations of the surrounding countryside, including intensive field surveys, began to be an integral part of field research. Robin Osborne was one of the earlier historians to focus on the countryside as the productive base for the classical city. ${ }^{7}$ Religious festivals coincided with agrarian calendars while sacrifices (requiring livestock) served to seal the relationship between city, countryside and the gods. Osborne's model of the classical city depicts cultivated fields worked by citizens who as hoplites also defended their borders; an image in sharp contrast with the later professional armies and increase in city walls. ${ }^{8}$ Osborne's views are rooted in Athens and Attika. Most of the population of Attika is believed to have lived in the countryside, as indicated by Thucydides (2.16.1) and confirmed thus far by survey data. The populations of other poleis in Classical Greece, however, appear to have been concentrated in towns, also indicated by field survey data. ${ }^{9}$ Susan Alcock noted the impact on Hellenistic Greece as local shrines often fell to neglect, while major country sanctuaries continued and even rose in popularity, such as those for Demeter..$^{10}$ But this does not mean that towns were made up of 'city-folk' only, nor that the

is more recently being explored from several angles, e.g. the contributions in Engels, et a. (2019), Häussler and Chiai (2019), and Scheer (2019).

6 Braudel's La Méditerranée et le monde Méditerranéen a l'époque de Philippe II, first published in 1949 with a revised English edition in 1972, revolutionized the study of history by correlating geography, socio-economics and political history. See Cherry et al. (1991) and Bintliff (1991) for the impact on archaeology. Russian archaeology took an earlier turn in this direction, e.g. Rostovtzeff's emphasis on regional economies in the Hellenistic and Roman worlds, Rostovtzeff (1941) and (1957), and Shcheglov's surveys in the northwest Crimea in the 1950s, see Shcheglov (1992) and Carter et al. (2000), 714. Also, German Landeskunde, developing in the nineteenth-century; Kirsten et al. (1956), discussed in Bintliff (2006), 23 .

7 Osborne (1987).

8 Osborne (1987), 164: "The city which in the fifth century had fought for its fields and had maintained its identity through border disputes and the military training which they involved, in the third century was reduced to having a quibble about the unproductive mountains settled by a third party in a piece of diplomatic play-acting. In a process of gradual separation warfare became divorced from the farmland and from the farmer, and the Greek city lost its essential identity."

$9 \quad$ Shipley (2002); Bintliff (2006), but see also the nuances in Lang (1999). Remote sensing and other new technologies of sub-surface surveying are changing scholars' perceptions of landscape use; e.g. for Asia Minor: Pirson (2012) on the countryside of Pergamon, or Lohmann et al. (2019) on Latmos, among numerous others.

10 Alcock (1994). Alcock attributes this to a demographic decline combined with increased competition between wealthy families and cities. Hero-cults were also used in this period to mark places of significance, Alcock (1997). 
landscape was desolate. In the John Bintliff's model, citizens were "farmers by day, urbanites at night," and would typically have owned land within an hour's walk or so. ${ }^{11}$

The difference between city and countryside in this context is more a matter of time and season than a hard division of space. There would seem to be less of a need to use sanctuaries to bind the rural periphery to the urban center if this were a regular part of peoples' lives anyway. Yet the city-countryside axis has been a steadfast criterion in distinguishing sanctuaries over the past decennia, and despite Osborne's and Bintliff's shift in focus to the countryside, the point of reference is still the built-up town center. This is part of the legacy of the Central Place Theory, developed by Walter Christaller in the 193os. ${ }^{12}$ Drawing on Von Thünen's nineteenth-century model of the 'isolated state', with various economic zones radiating from the center, ${ }^{13}$ Christaller's theory presumes a strong hierarchical categorization of space (and society) with a natural inclination towards centralization and an acute awareness of borders. ${ }^{14}$

The core-periphery model has strongly influenced the terminology used to classify ancient Greek cities and their sanctuaries. Terms such as 'extra-mural', 'sub-urban', 'extra-urban', and even the negation 'non-urban'15 all reference an urban context and imply a degree of correspondence between the sanctuary and the political center to which the wider territory belonged. Yet certain major shrines were considered to be far removed from the centers of civilization, especially among the colonies in Magna Graecia. ${ }^{16}$ Scholars in the early twentieth century were at a loss to explain these seemingly isolated cults: if they were as important as their architecture suggests, why were they founded so far away from the centers of power? ${ }^{17}$ Three explanations were developed. The first is the 'indigenous' theory, which proposes that these were native cults later appropriated by the Greeks along with the territory in which they were

11 Bintliff (2006), 30. Ruschenbusch (1985) indicates the size and catchment area of the average polis, with a radius of $5^{-6}$ kilometers and a population of $2000-4000$ persons; Athens was a 'Megalopolis' (cf. the lower figure of 150,ooo estimated by Osborne (1987), 49); Bintliff (2006), 20-23; also Bintliff (2008), and Hansen (2004).

12 Christaller (1933).

13 Von Thünen (1826).

14 Carried further in the World-Systems Analyses of Hopkins and Wallerstein (1982); see also Hall and Nick Kardulias et al. (2011).

15 De Polignac (1995), 32-88.

16 E.g. the shrine of Hera Argiva on the Sele is $8 \mathrm{~km}$ from Poseidonia, the Heraion at Lacinia, $9 \mathrm{~km}$ from Croton, Apollo Alaios on Cape Ciro, $40 \mathrm{~km}$ from Croton; also smaller sanctuaries such as San Biagio, $7 \mathrm{~km}$ from Metaponto, and Francavilla Marittima, $18 \mathrm{~km}$ from Sybaris.

Also Graf (1982), 166; re-addressed in Graf (1996). 
located. ${ }^{18}$ The 'Mycenaean' theory holds that these sanctuaries were remnants from Mycenaean cult-sites, later appropriated by the natives, then finally reappropriated by the Greeks. ${ }^{19}$ Finally, the 'pre-Colonialist' theory assumes they were part of the 'first contact' between pre-colonial Greeks and indigenous peoples, and were later appropriated by the second wave of Greeks as colonists. ${ }^{20}$ All three views have in common the assumption that these cult places pre-date the Greek cities and had further little to do with them; despite its teleological overtones, the use of blanket qualifiers such as 'extra-mural' or 'extra-urban' was actually meant to underscore this distant relationship. ${ }^{21}$

In 1967 , however, Georges Vallet showed that a number of rural sanctuaries also post-date the foundations of the cities; therefore other explanations had to be sought for their location. ${ }^{22}$ He postulated that, rather than being a cultural or historical accident, they were very much relevant to the life of the polis. He broke down the then current singular category 'extra-mural' into 'suburban' and 'extra-urban', emphasizing the relationships of sanctuaries with the cities in their proximity. In his carefully defined typology, sub-urban cults are generally close to town (within 1 kilometer), are low-key and are usually concerned with fertility or agrarian or pastoral issues. Extra-urban cults (typically 7-10 kilometers from town) are again subdivided into two types according to size: the smaller sanctuaries tend to be located on the surrounding hills overlooking the plain of the city, perhaps with small settlements of their own; ${ }^{23}$ the grand monumental sanctuaries, for the civic gods, could be located farther away but were founded with or after the cities to which they were related. As with the smaller shrines, much like the sacred villages of Asia Minor, settlements at these sanctuaries were common, although these are interpreted as

18 Oldfather (1912); Giannelli (1924); Ciaceri (1940), 2off. These theories are further discussed in Asheri (1988), 3, who believes them to be colored by Italian nationalism.

19 Pugliese Carratelli (1962).

20 Dunbabin (1948), 181ff. He takes issue with the 'indigenous' view as proposed by Ciaceri (1940) and builds his theory instead on analogies with colonialism in the British Empire, especially in Australia and New Zeeland; De Angelis (1998).

21 Pugliese Carratelli (1962); Hermann (1965).

22 Vallet (1968), except for San Biagio that antedates Metaponto. Zancani-Montuoro pointed out in her response on p. 170-178 of the same volume that Francavilla Marittima also antedates Sybaris, allowing for indigenous influence. This important observation, however, does not detract from Vallet's main point on the significance of these sanctuaries for the polis, albeit it at a later point.

23 Vallet (1968), 89-91; some sanctuaries in this type were also located along the coast. Either way, they would almost seem to have a protective position around the main settlement. The deities at these sites are unfortunately unknown. 
housing for cult personnel, or sometimes as garrisons when fortified. ${ }^{24}$ Political and historical documents found at these remote sites pertaining to events that concerned the civic body (e.g. decrees, citizen registries, priesthoods) testify to their strong bond with the polis, just as with the case studies from Asia Minor discussed in this volume. Vallet sees these sanctuaries as particularly vital to the political life of the polis, just as the land itself is vital - they anchor the polis to its territory while opening it up to the wider community, transcending its boundaries. ${ }^{25}$ This concept would later be carried much further by François de Polignac.

Since Vallet's work, the categories of 'sub-urban' and 'extra-urban' have become commonplace in studies on sanctuaries, albeit with further nuances and sub-divisions. One of the clearest examples is Ingrid Edlund-Berry's typology, with 'extra-mural', 'extra-urban', 'political', 'rural', and 'nature' as categorical settings for sanctuaries in Etruria and Magna Graecia. ${ }^{26}$ She observes that in Etruria extra-urban sanctuaries are generally an extension of the urban sphere and could be located anywhere, whereas in Magna Graecia they are principally located at territorial boundaries. Like Vallet, she believes these high-profile sanctuaries had mediatory roles: they marked the frontiers of the Greek world while providing "a neutral space as a meeting place for different groups of colonists and perhaps even non-Greeks." 27 In many ways Edlund-Berry's views are similar to Vallet's with the important exception that she attributes less significance to size and distance and more to their function in the human landscape as criteria. This is a crucial distinction, and one which is much more helpful in understanding sanctuaries as part of a sacred landscape

24 Vallet (1968), 93. The role of the military at rural cults deserves more attention in general. Vallet sees the "piccolo città santa" (p. 93, n. 6o) as being fortified during processions and festivals (on the risk of violence at processions, see Chaniotis (2006), 211-213). In his response to Vallet in the same volume, p. 216-220, Roland Martin discusses the suburban cults of Asia Minor as being involved in a peripheral defense system for the city; he further considers certain extra-urban cults to primarily have served the indigenous or mixed populations from the more remote regions, and so functioned as sacred neutral zones for religious, commercial and political interaction.

25 Vallet (1968), 94 : “... une fonction politique active et ceci dans une double perspective: comme marquée d'une empreinte matérielle et surtout morale de la polis sur son territoire et d'autre part comme le lieu géométrique de rencontres, je n'ose dire panhelléniques ou panitaliotés, mais qui, en tout cas, dépassent largement le cadre de la polis.".

26 Edlund-Berry (1988), 41-43. These categories are reflected in Pedley (2005), 39-52, as 'sanctuaries in Nature', 'interurban', 'urban', 'suburban', and 'rural'.

27 Edlund-Berry (1988), 143. She further observes that sanctuaries associated with cities, but also used by non-locals tended to have a more monumental appearance, p. 138. 
accommodating not just the political, but also the social, economic and, of course, religious spheres.

Several other scholars have further elaborated these categories, adapting them to fit their own particular area of study. ${ }^{28}$ What they all show is how a close examination of the archaeological and historical data leads to a new revision of the theoretical categories, each tailored to the specific questions of the researcher. ${ }^{29}$ David Asheri took an extreme position in 1988 in practically calling for a moratorium on theory until each and every case throughout the Greek world has been analyzed in detail. ${ }^{30}$ Although this is unrealistic, he is correct to show how static and context-sensitive such categories are, and how they hardly accommodate evolving complexities such as synoikisms, territorial expansion, or urban relocations. In short, 'extra-urban' cults may not always have been extra-urban, and he seems to find this category of little use when it comes to interpreting these outlying sanctuaries. ${ }^{31}$ Regarding the situation in Asia Minor, I concur with his views and have therefore avoided the term as far as possible, preferring instead to call them 'country sanctuaries.' ${ }^{32}$ As a heuristic aid such classifications are valuable but can easily lead to unintended associations and retroactive projections when used indiscriminately. The adjective 'country' is less prone to these biases while still conveying the landscape setting as well as a degree of territoriality belonging to the sanctuary

28 The volume Placing the gods, Alcock and Osborne (1994) was especially influential in bringing the studies of outlying sanctuaries to the foreground, with several case studies showing how existing theories, particularly de Polignac's 'bi-polar model' (more below) could be applied, rejected or modified. Although the subtitle of the volume is broadly 'Sanctuaries and sacred space in ancient Greece', nearly all of the contributions concern political aspects of sanctuaries and their relations to borders.

29 Such as Rosina Leone, who like Vallet uses distance as a criterion, besides cult type and function, to classify sanctuaries in the chora of Magna Graecia as 'rural', 'frontier', or 'peripheral'; Leone (1998), 16-18. 'Frontier' sanctuaries in her view are political and generally later than the rest; 'peripheral' sanctuaries were mostly feminine cults and were pivotal because they concerned both the fertility of the citizens and the countryside; 'rural' sanctuaries were more masculine and chthonic, oriented to the local population, Leone (1998), 23-30, 31-35. See also Boffo (1985) for Asia Minor.

30 Asheri (1988).

31 Asheri (1988), 6, 7-10. He continues with three provocative case studies, two sanctuaries in the environs of Messina and one close to Rhegion, to argue that population movements and the creation of new ethnic suburbs within the polis were more likely drivers than external political factors. A common thread with his predecessors, however, is that these sanctuaries served as a point of cultural or ethnic identification, as well as a zone of contact with the outer world.

32 Alternatively they are could also be designated as 'outlying' sanctuaries, although this is also problematic as it implies a single perspective, outlying from where and to whom? 
itself, an aspect particularly relevant concerning the extent of sacred lands owned by the shrines, as well as the extent of their communities.

The studies discussed so far primarily deal with the meaning of the geographical distance of remote sanctuaries from towns and what their relevance was to the community. At the same time, however, a parallel line of thought was being developed on the geography of the gods as a structuring factor in the ancient Greek mind. Scholars focusing on mythology took an early interest in the urban-rural axis while establishing a canon of the Greek pantheon that classifies the realms of the individual gods according to the corresponding areas of human concern..$^{33}$ Oppositions believed by structuralist anthropologists to be universally human were matched to divine domains through sets of oppositions, e.g. male-female, outdoors-indoors, cultivated-wild, rationalirrational, and center-periphery, to interpret ways in which the Greeks conceptualized their world. ${ }^{34}$ This line of thought was subsequently extended to the polis to show how the pantheon of gods and the ideas they embody were intrinsic to the socio-political and spatial organization of the Greek community. ${ }^{35}$ Sanctuaries are at the intersection of the human and divine, and Albert Schachter observed that site location is largely determined not only by natural features in the landscape (e.g. mountains, springs, trees, or passes, roads, transitional areas), but also by their social and political connotations. ${ }^{36}$ The Olympian deities were thus anchored through their shrines to topomorphic types of places in civic territory which corresponded to the social spheres over which they presided. ${ }^{37}$ Sanctuaries to Athena, Aphrodite, Apollo (Pythios) are typically found in the urban center as these three were concerned with

33 See esp. Nilsson's monumental Die Religion der Griechen, 1927. But also Nietsche's Die Geburt der Tragödie aus dem Geiste der Musik, 1872, articulating the archetypal binary pairs of opposites between the Apollonian and Dionysian spirits (e.g. cultural-natural, rationalirrational, creative-destructive, civilized-wild). The later ideas borrowed from structuralist anthropology and applied to Greek mythology have been greatly influential, especially as developed by Jean-Pierre Vernant, Pierre Vidal-Naquet, and Marcel Detienne; Vernant (1965b); Vernant and Vidal-Naquet (1972); Detienne and Vernant (1974).

34 Vernant, for example, discussed the contrast between Hermes and Hestia as embodying the differences in ideals between masculine-outdoors-travel with the feminine-indoorshome (hearth), Vernant (1965a).

35 And how the polis determined religion, see esp. Sourvinou-Inwood (1990). See further Bruit Zaidman and Schmitt Pantel (1992), Cole (1995), and Burkert (1995). Also Morgan's work on the ethnos in a similar vein: Morgan (1990), 1-25; also Morgan (1997) and (2003), esp. 107-163 'communities of cult'.

36 Schachter (1992), 57: site location as "a balance, sometimes delicate, sometimes crude, between the needs of policy and the needs of cult." His study revolves around the sacred landscapes of seven poleis: Argos, Corinth, Eretria, Thasos, Thebes, Athens, and Sparta.

Also de Polignac (1984), see below. 
political organization and civic matters; Dionysos was most at home in the 'irrational' countryside, but so were Zeus and Demeter, who were worshiped there as agrarian deities and at corresponding sanctuaries in town; Hera and Poseidon marked the territorial borders of aggressive poleis, while Artemis sanctuaries are generally found near transitional zones or disputed borders. ${ }^{38}$

Schachter's spatial patterning of the divine, although suspiciously neat, resonates with several sites in mainland Greece. In Asia Minor, however, with its mosaic of cultural influences, many other factors were also at work, producing unexpected combinations, such as 'wild' Dionysos at the center of Teos, or Artemis on the agora at Magnesia on the Meander. ${ }^{39}$ Hekate, guardian of marginal waysides, gateways, and crossroads, became the principal goddess of Stratonikeia. Caution must be used in applying such patterns, and one must take into account the many local variations that made the divine constellation of each polis unique. ${ }^{40}$ Nonetheless, Schachter's work highlights the place of the gods in the wider political, social, and sacred landscape of the polis, and goes beyond the labels of 'urban' versus 'extra-urban' by interpreting the setting of cult through psychology and myth.

\subsubsection{Frontier Sanctuaries and the 'Bi-Polar' Model}

The scholar most often cited with regard to outlying sanctuaries is François de Polignac, who presented his 'bi-polar model' in 1984 in his seminal work $L a$ naissance de la cité grecque. ${ }^{41}$ His argument on the pivotal role of sanctuaries in the rise of the polis acknowledges the topomorphic attributes of the gods, but concentrates on the historical relevance of location. In doing so he elaborates on what he calls the 'non-urban' sanctuary, ${ }^{42}$ although his main concern

38 On Artemis he adds that "In colonies the disputed area, in the early stages of settlement, is the city itself." Schachter (1992), 36. Cole explores in more detail the location of cults for Artemis and Demeter; Demeter Thesmophoros is often a cult that links town to country, usually at the edge of town or in remote places in town, see Cole (1994); on Artemis cults being located at more dangerous border areas, see Cole (1999-2000) and (2004), chapters 6 and 7 .

39 Although highly aggrandized by Hermogenes in the third century вс, both sanctuaries at Teos and Magnesia on the Maeander date from the late Archaic period.

40 Polinskaya (2006). Sourvinou-Inwood (1990), 300-301, 318, who similarly categorizes the gods according to socio-political function, allows room for local variations according to individual polis' pantheons.

41 De Polignac (1984), revised and translated in 1995 as Cults, territory, and the origins of the Greek city-state.

42 Esp. de Polignac (1995), Ch. 2 'The nonurban sanctuary and the formation of the city'. In his discussion of Magna Graecia (p. 92) he identifies four basic categories of sanctuaries: the monumental urban sanctuary; the monumental non-urban sanctuary (his main focus); the non-monumental peri-urban (i.e. suburban) sanctuary; and the non-monumental 
lies with the grand sanctuaries typically situated at the outer perimeters of polis territory, i.e. the 'extra-urban' sanctuaries as Ingrid Edlund-Berry defines them. ${ }^{43}$ These sanctuaries, commonly dedicated to Hera, Poseidon, or Artemis, were in his view instrumental to the formation of the polis. They represent the boundaries of the civilized, agrarian world against the world of the wild and are seen as a means of bringing order to disorder; through these sanctuaries the gods provide true mediation between man and nature. Yet they are also often located at a second kind of border, that of political frontiers. ${ }^{44}$

De Polignac brings these sanctuaries to the fore as he contests the 'monocentric' model of the polis in which the principal sanctuary is located on an akropolis within the town center. While this model certainly applies to Athens and its development in the Dark Ages, it is not typical of most Greek poleis. ${ }^{45}$ The rise of the polis should be investigated not at its center but at the scene of action: the territory and the hardening of the borders that took place in the late ninth and early eighth centuries вС. The agrarian crisis of this time led to the increased cultivation of fallow land, pushing up into the wild regions where remote sanctuaries were (already) located. As Osborne had argued, these became contested areas as communities on either side began to organize themselves into hoplite forces to apply pressure on each other. Remote shrines, once marking the wilderness, were now at the heart of conflict. ${ }^{46}$ These frontier sanctuaries became territorial claims and focal points of pride for the victorious communal body. According to de Polignac this eventually sparked a form of urbanization that became what he calls the 'bi-polar city', with two foci of power: the inhabited center with a great urban sanctuary on an akropolis counter-balanced by a great extra-urban sanctuary located at the periphery of the chora. ${ }^{47}$ These two poles are physically linked through ritual: the festivals taking place at the frontier sanctuary but especially the grand processions

sanctuary in the outer territory. Stek (2009), 58-65 gives a good discussion of de Polignac's ideas in relation to Italic sanctuaries.

43 Edlund-Berry (1988), $75 \mathrm{ff}$.

44 De Polignac also referred to Vernant and Vidal-Naquet in his section on frontier sanctuaries as the prime intermediaries between man and nature or the gods, de Polignac (1995), 34-36, esp. p. 36 n. 3.

45 De Polignac (1995) 81-88 'The bi-polar city and the Athenian exception'; also discussed above in connection with areal and population sizes of cities.

46 Osborne (1987), 164; de Polignac (1995), 6o: "Religious sites, like the land itself, were the objects of a process of appropriation crowned by the building of a sanctuary that designated the frontier the group claimed for its territory in the face of its neighbor-adversaries."

47 "The effect of the monumental, liturgical, mythological, and historical importance of the great extraurban sanctuaries is to give the civic and religious space two poles, and it is not the case that the urban pole is the more important," de Polignac (1995), 82. 
leading out from the town across the countryside and to the sanctuary on the border. ${ }^{48}$ Such processions were not necessarily only political but could also involve agrarian rituals or initiation rites, showing how important the cult was to the vitality and future of the community.

De Polignac's ideas are original, greatly expanding Vallet's political interpretation of frontier sanctuaries, and have been influential in raising awareness of the countryside as a vital component of the polis. Despite this, he has drawn heavy criticism for being overly focused on theory and less on solid evidence, and thus imposing the bi-polar model on situations that cannot always bear it. ${ }^{49}$ Also, his emphasis on political boundaries illumines only one aspect of these cults at the cost of several others; not every border sanctuary was political or militant. ${ }^{50}$ Furthermore, his bi-polar model isolates both urban and non-urban political sanctuaries from the abundant sacred landscape in all its diversity, of which they were also an integral part. Finally, he is accused of leaning too heavily on structuralist oppositions, such as core-periphery, citycountryside, civic-wild, all laden abstractions in themselves. ${ }^{51}$

Nonetheless, de Polignac's thesis has inspired several studies on outlying cult places which have brought important nuances to this model. ${ }^{52}$ Fritz Graf, for example, discussed the ritual of processions with regard to the momentum of direction: centripetal processions drew the demes of the chora into the center of town, e.g. the Panathenaia, or the Great Dionysia, while centrifugal processions crossed the countryside to a remote sanctuary. ${ }^{53}$ Tonio Hölscher discusses the processions to major shrines in the chora of Attika as a means of

48 De Polignac (1995), 40-41. De Polignac's archetype is Argos and the Argive Heraion, on a promontory across from Argos and overlooking the fertile Argive plain: de Polignac (1995), 41-43 and 52-53. Cf. Hall (1995), who argues for a much later date for Argos' appropriation of the Heraion. Bintliff (1977b), 98, in a discussion of ceremonial landscapes, addresses processions as power displays, drawing on Vogt (1968).

49 Esp. the Argive Heraion, Hall (1995); on the sanctuaries in the chora of Metaponto, Carter (2006), 16o and pers. comm. 11.2006; on the sanctuary at Francavilla Marittima, Kleibrink et al. (2004), 52; on the Heraion at Foce del Sele, Malkin (1996), 78.

50 De Polignac also recognizes the role of border sanctuaries as places of meeting and mediation, de Polignac (1995), 36 and de Polignac (1994). For frontier sanctuaries as sacred channels of safe passage, see Sinn (1996).

51 Antonaccio (1994), 81-86 and Polinskaya (2006), 65. An overall assessment is presented in McInerney (2006), 37-38 and Pedley (2005), 52-56. Against the core-periphery model in general, see Sherratt (1993), "Who are you calling peripheral?" Dependence and independence in European prehistory'.

52 Most notably the contributions in Alcock and Osborne (1994), Placing the gods. See also Susan Guettel Cole's application of de Polignac's ideas (among others) in interpreting the role of the female in ritual landscapes, Cole (2004). 
creating spatial hierarchy in the territory of the polis; similar motivations may also be found behind the New Year processions from Miletos to Didyma, as Alexander Herda has argued. ${ }^{54}$

Frontier sanctuaries could also fulfill a different political role: one of providing safe passage across territorial borders, something that was not taken for granted in an era when raids and political violence were considered normal. Ulrich Sinn considers this function for several sanctuaries in the Peloponnese located on mountain ridges that border two or three political territories; they are in rugged and inhospitable terrain, but were highly visible due to their monumental architecture and prominent locations. ${ }^{55}$ Rather than aggressive signs of territorial claims, Sinn sees these frontier shrines as thresholds, creating access and platforms of communication through the joint festivals that were held there, rather than in the towns of the mutual parties; invitations were de facto treaties of friendship between poleis. ${ }^{56}$ The rise of the recognition of asylia and the invitation to panhellenic games in the Hellenistic period is testimony to such gestures of goodwill on a 'global' scale, in which outlying political sanctuaries occupied this mediatory role; this is discussed in more detail with regard to the sanctuary of Hekate at Lagina in Chapter 5 .

There was also an economic side: poleis that could be accessed via these sacred channels were more likely to prosper as they attracted trade via wandering workshops, traveling artisans and artists. ${ }^{57}$ Country sanctuaries facilitated contact across different kinds of economies. James McInerney postulated that the risk factor implicit in the civilization-wilderness polarity is much more fundamental to the mental structuration of space than the urban-rural axis. ${ }^{58}$ Wilderness areas are typically used for grazing, and pressure on borders often

54 Hölscher (2013); Herda (2006) and (2011).

55 Sinn (1996), 70-74, e.g. the joint organization of the frontier sanctuary to Artemis Hymnia by Orchomenos and Mantineia. He develops the idea of asylum and major outlying sanctuaries put forth in Sinn (1993), 102-107; few of these shrines have been excavated, and he largely draws on Pausanias.

$5^{6}$ Sinn discusses the example of the sanctuary of Artemis Limnaia at the frontier between Messenia and Lakonia. Apparently this was contested space between the two poleis and yet they held joint festivals here, with common assemblies and sacrifices, Sinn (1996), 71, and n. 23. De Polignac also discusses the meditatory role of sanctuaries, more in the context of peer-rivalry in quasi-neutral zones, de Polignac (1994).

57 Cycladic construction techniques in Alipheira, and Corinthian tiles in Aetolia are examples of 'wandering workshops'; the Artemision of Ephesos, protected through the grant of asylum, functioned as an international bank in the Hellenistic period, Sinn (1996), 67-68. Debord (1982), 24-25, also on sanctuaries with the status of asylia as providing additional safe access and economic protection.

$5^{8}$ McInerney (2006), 38, 56. He refers to Vidal-Naquet on the use of wilderness in civilization, p. 39 n. 21. 
came from the pastoral sector, marginalized by the expanding cultivated fields. The best lands available were sometimes made sacred in order to avoid claims and disputes. Herds were generally allowed to pass through while grazing, as Sinn argued, or during festivals for the sacrifices. ${ }^{59}$ However laws ensured short stays to prevent both overgrazing and squatters' claims. ${ }^{60}$ The ongoing stabilizing effect on the community and its economy that remote sacred areas held is precisely due to their neutral position.

The location of country sanctuaries may be determined by a mix of factors. Proximity to cultivated lands, natural features, areas too wild or remote for human habitation are only some of the reasons. ${ }^{61}$ Others will have began as centers of their own local communities, only later to be absorbed and marginalized through synoikism and annexations by larger poleis, as with Magna Graecia but also some of the cases in this study. Still others may mark the direction of future territorial advancement. Irad Malkin uses de Polignac's model to explain the sudden appearance in the early Hellenistic period of sanctuaries of Zeus Ammon along the western border of the territory of Cyrene, encroaching upon rival Carthage. ${ }^{62} \mathrm{He}$ sees the real value of de Polignac's model in understanding the later Hellenistic development and expansion of poleis. ${ }^{63}$ Elif Koparal notes the richness of the ritual landscape in the frontier zone between Klazomenai and Teos, but sees the shrines as part of a larger sacred network. ${ }^{64}$ Susan Alcock interprets rural shrines as central to the construction of urban identity and internal awareness of territory, rather than as frontier markers to other communities. Major rural cults continued to play an important role as a ritual way for "urban dwellers" to "take possession" of their land, even in the Roman period, while at the same time providing an outlet for the urban elite to manifest themselves. ${ }^{65}$ This is what made them so attractive to Rome as controlling devices - they could be either amplified, e.g. through the addition of the imperial cult, or dislocated in adverse regions as frontiers were redrawn. ${ }^{66}$

\footnotetext{
$59 \operatorname{Sinn}(1996)$.

6o McInerney (2006), 53-55.

61 E.g. Nordquist (2013); Miles (2016); Koparal (2019).

62 Malkin (1996).

63 Malkin (1996), 81, using de Polignac's concepts in what he calls a "pragmatic approach" rather than the "heavy-symbolism "intentionalist" methodology.

64 Koparal (2019), also discussing the re-use of older shrines.

65 Alcock (1993), 161, on the changing sacred landscape of Greece under Roman rule further observing an overall decline of minor rural shrines.

66 Cults were thus used as a disciplinary measure; e.g. the cult image of Artemis Laphria of Kalydon in Aetolia was reassigned to Nikopolis and Patras; Tegea lost the cult statue of Athena Alea to Rome, Alcock (1993), 157-158. This is similar to Pompey's radical
} 
These studies demonstrate the very wide variety of shrines labelled by scholars as 'frontier' sanctuaries, from the archaic era through to the Roman period, underscoring how difficult it is lump them together under any one category other than their relative location. A common current, however, is the general acceptance, albeit tacit, of the core-periphery model and urban-rural bias as explanatory for their function.

\subsubsection{Opposition: the Continuum Perspective}

The polarity between town and countryside has been called into question by scholars who consider it to be a modern, post-industrial paradigm retrojected onto the Greek mind. The terminologies used to qualify sanctuaries according to location (e.g. 'sub-urban', 'extra-urban', even 'non-urban') implicates the urban bias as starting point, as mentioned above. The Greeks themselves only used descriptive terms - a sanctuary was in the chora, near local landscape features (e.g. on a mountain or hilltop, by a stream or forest, etc.) or near town pro poleos, 'before the town', indicating the outsider perspective of farmer or traveler. ${ }^{67}$ Terms were often loosely used in antiquity and the word polis could equally refer to a political community, urbanized or not, its wider territory, or just its built-up center. Yet over the years, modern scholars have subjected these terms to extensive definitions and refinements in order to produce a heuristic vocabulary. ${ }^{68}$ In this respect, asty and chora are now the primary terms used respectively for the built-up center and the surrounding territory; together they constitute the geographical polis as we know it, but we should not assume they were as strictly defined in antiquity.

Studies on the ancient polis generally distinguish between town and country with the goal of drawing the countryside into the picture as a serious object of study in itself. Until recently this distinction has seldom been questioned. In social studies, however, objections to this classification were already being raised long ago. In searching for a good description of the difference between peasants and city-dwellers in Latin America, anthropologist Robert Redfield

reorganization of the area around the powerful sanctuary of Pontic Komana, one of Mithridates's hearths during the wars, see Debord (1982), 6o-61.

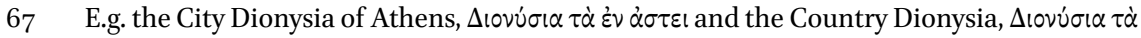

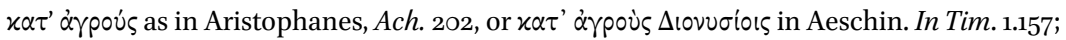
see Polinskaya (2006), 67-74, and n. 32. Demeter sanctuaries are often described as being

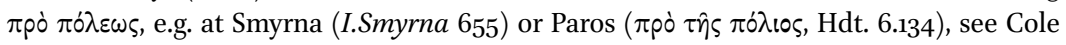
(1994), 211-212.

68 E.g. Sakellariou (1989), Hansen (1997) and (2007) and the publications of the Copenhagen Polis Centre. Hölscher (2013), 48 Abb. 1 gives a scheme showing the concentric circles from asty to eschatia (the outer ring of the chora). 
came to the conclusion in 1953 that dividing societies along a rural-urban dichotomy was too simplistic and ignored the wide spectrum of variations. ${ }^{69}$ He introduced instead the concept of a 'rural-urban continuum', a term that acknowledges the opposition while negating it at the same time. Regarding town and country in ancient Greece, Sally Humphreys decided that the terminology in question pertains to "a potential contrast which in any given society may be minimized (continuum) or emphasized (dichotomy)."70 Factors that in her view should considered include: the degree of centralization, i.e. size and densities of settlements (nucleated or dispersed); popular beliefs or attitudes about city-dwellers versus country-dwellers; hardness of boundaries, both physical (walls) and institutional (laws, policies); and the degree of traffic between the boundaries. ${ }^{71}$ Time is also an important measure. In an effort to understand the rise of federal sanctuaries, Emily Mackil argues that country shrines generally developed from the interaction between multiple local or regional communities, rather than being a sign of territorial domination by a sole polis. $^{72}$

The distinction between town and countryside is thus not always as clear cut as it might seem. Even the juxtaposition of the two entities exposes the implicit modern values ascribed to either category. Irene Polinskaya demonstrates that de Polignac's bi-polar model, while bringing attention to the countryside, in fact hardens the opposition through its either/or approach, leaving between the poles only empty 'space', space that is in reality teeming with life social, economic, political, and sacred. ${ }^{73}$ Such neat abstractions cannot do jus-

69 Redfield (1953), arguing that the farmer, the vagrant, and the suburbanite all make use of the countryside in different ways. Useful discussions of this are found in Wheatley (1972), 602-6o5, and Stoddart (1999), 910. The term 'rural-urban continuum' has also been used by the U.S. Census Board in county classification; wayback.archive-it .org/5923/20120620120804/http://www.ers.usda.gov/Briefing/Rurality/RuralUrbCon.

70 Humphreys (1978), 134.

71 Asheri's theory on the relocation of certain ethnic groups to just outside the city walls in Messina, with extra-urban sanctuaries to 'service' these groups, shows one of the complex situations in antiquity, Asheri (1988), mentioned above. See also Bintliff's anthropologically inspired approach to Minoan and Mycenaean peak sanctuaries as ritual places which were fully integrated with the cycle of the landscape and the economic needs of the communities, Bintliff (1977b), 92-104 in his section on 'Ceremonial sites and the landscape', and especially 98-104; discussed in more detail in his dissertation Bintliff (1977a), 145-170.

72 Mackil (2013b), 149: "It now seems unlikely that poleis initially demarcated their territories by the construction or monumentalization of rural sanctuaries at the borders. Rather, it appears that religious communities existed prior to the formation of particular political communities, and the former had a deep impact on the creation of the latter."

Polinskaya (2006). 
tice to the great variety in cults and sanctuaries or the 'local religious worlds' of communities, many of which preempted the processes of urbanization. ${ }^{74}$ In her view, qualifiers such as 'extra-mural' are meaningless as city walls just followed the defensible contours around the settlement, and are a relatively late phenomenon. ${ }^{75}$ Political centers come and go, so any spatial reference to these must include the dimension of time. Finally, when it comes to cult, the categories of 'urban', 'sub-urban' and 'extra-urban' flatly ignore the uniqueness of each polis' constellation. Instead of subdivisions based on oppositions, Polinskaya argues that sacred topography of a polis should be approached as "a religious and spatial continuum. ${ }^{76}$ Like Asheri, Polinskaya calls for a detailed approach that considers each polis as a unique entity; unlike him, she expects too many differences to warrant any generalizing theories.

Studies on the extent of polis territory lean more towards a continuum view. Bintliff estimates that the most poleis would have had been small, with a territorial radius of maybe five or six kilometers and a population of 4000 to $6000 .{ }^{77}$ Citizens would have been intimately familiar with the surrounding landscape where the base of their livelihood lay. The shrines of these poleis, however distant from the town center, would normally have been much closer together, and hence more frequently accessible, than in a megalopolis such as Athens. This generally fits Horden and Purcell's view of the Mediterranean as a network of micro-regions, or 'micro-ecologies', each with its own unique topographical situation, often bordered by natural features such as mountains, rivers, or sea. ${ }^{78}$ Though less adamant than Polinskaya, they also envision ritual

74 Polinskaya (2006), 65: "The main source of religious diversity was the existence of multiple local religious worlds corresponding to the geo-political fragmentariness of the Greek world throughout antiquity."

75 Polinskaya (2006), 76-77, arguing that the Greek city had nothing like the Roman pomerium. Yet walls arguably had a representational value, e.g. the many images of Tyche crowned with city walls. Moreover the increased zoning of burial sites indicates a clear demarcation between the space of the living and that of the dead.

76 Polinskaya (2006), 8o, 85. One of her examples are the many sacred places connected by the Molpoi procession from Miletos to Didyma. This inscription, LSAM 5 , is discussed extensively in Herda (2006). Graf saw this same inscription as lending support for centrifugal procession typical of the bi-polar model, referring to the space between the two poles as 'wild'; see above and Graf (1996), 65.

77 Bintliff (2006), citing Ruschenbusch (1985). The figures are drawn from Greece proper, and do not include the colonial cities of Magna Graecia, which generally had larger territories with larger populations; see the inventory of the Copenhagen polis Centre, Hansen and Nielsen (2004) and now Hanson and Ortman (2017).

78 Horden and Purcell (2000), esp. 403-46o, "The geography of religion" in their monumental work The corrupting sea. They clearly state that their views are neither Durkheimian (i.e. religion as the reflection of social cohesion) nor Marxistic (i.e. religion as imposed by 
topography as reinforcing a continuum of city and countryside. ${ }^{79}$ They stress how tightly integrated it was with the 'productive environment', situated in the economic countryside as well as at sanctuaries, with trade opportunities through the seasonal fairs during the festivals. ${ }^{80}$ The sacred landscape also overlaps with the 'perilous environment'; places of cult could be perched at numinous but also dangerous, albeit sublime, positions in the environment. ${ }^{81}$ Such places were commended to the gods while their prominent sanctuaries acted as a signpost for mortals. ${ }^{82}$ A third role concerns their interaction with the wider environment, inducing mobility and facilitating regional alliances. As Sinn and McInerney had noted regarding frontier shrines, Horden and Purcell stress ways that sacred journeys to remote sanctuaries intentionally crossed and connected various kinds of ecological zones, involving different production types (e.g. agriculture, herding, fishing, hunting) and different types of terrain (e.g. plains, forests, mountains). ${ }^{83}$ As points of connection, sanctuaries were often located at passages where one domain crosses over into the next. Because of this they could also be buffer zones between territories; e.g. Corinth and Megara were separated by the sanctuary of Poseidon at Isthmia, and Megara and Athens were separated by the sanctuary of Demeter at Eleusis. In fact, because many of the major rural sanctuaries antedate the poleis with which they came to be associated, Horden and Purcell believe it likely that the siting of the city was predicated on the region of the sanctuary, rather than vice-versa. ${ }^{84}$

decision-takers) nor do they suggest any kind of environmental determinism, p. 406-407. There is no room here to provide an adequate assessment of their monumental work; for critical reviews see, among others, Lucia Nixon in JRS 92 (2002), 195-197; Anthony Molho in the Journal of World History 13 (2002), 486-492; James Fentress \& Elizabeth Fentress in Past \& Present 173 (2001), 203-219 ('The Hole in the Doughnut').

79 Horden and Purcell (200o), 435-436, $45^{2}$.

8 o Cf. Debord (1982), 24-25; Sinn (1996); Chandezon (2003); McInerney (2006).

81 Semple (1927); Nordquist (2013) argues that Greek sanctuaries were rarely located in numinous settings; also Williamson (2020a) on sanctuaries and the sublime.

82 Shrines could be used to mark perilous places, or for wayfinding: e.g. Semple (1927) on dangerous 'templed promontories' and Nixon (2006) on the role of roadside chapels and icon stands in medieval and modern Sphakia on Crete, which both shape the sacred landscape and are shaped in return by the roads they mark. New Roman highways had a similar impact in Etruria, e.g. Ward-Perkins (1972).

83 Sinn (1993) and (1996); McInerney (2006) discussed above.

84 "The location of cities, then, did not bring about the construction of shrines in between them. Rather, religious imperatives led to the construction of shrines in out of-the-way places: cities subsequently developed on the nodes in the routes joining these sacred places," Horden and Purcell (2000), 457. This would accord with Turner Turner (1973), briefly discussed in the introduction; also Dignas (2002a), 243. An example in Asia Minor 
Sacred landscapes can shift in composition and especially meaning. Time, again, is a crucial factor in the ways that sanctuaries were perceived and in the roles that they were given, but also in the configuration of sacred movement across the landscape. Modifications to this space are therefore highly significant as they can manipulate, change, or reengineer the common experience; this is particularly the case where sanctuaries or other landmarks, especially tombs, are concerned. Viewing sanctuaries as magnetic elements in a spatial continuum means that they must be seen against the complexities of their landscapes, and cityscapes, in a fluid way that incorporates movement and change. Phenomenological approaches to space offer some guidelines into the many alternative ways of approaching space, such as Tim Ingold's 'taskscapes', focused on functionality, or Christopher Tilley's social and existential space, among other types. ${ }^{85}$ Each kind of space, and the symbols, boundaries, and stories that it harbors, will come with its own kinds of experience and prescribed ways of moving through it, reinforced by pathways, monuments and inscriptions - experiences that were clearly entangled. ${ }^{86}$ Much more than a background, landscape is a chronotopic actor in this signifying system. The studies discussed here invite us to go beyond focusing on the civic, political, urban or rural value of individual country sanctuaries. What if we could truly consider them within the complexities of their extensive and dynamic networks - sacred, political, social, economic, and personal? This would surely lead to a much richer understanding of ways that they actually integrated landscape and community.

\subsection{Classifying Sanctuaries in Asia Minor - Greek/Anatolian or Urban/ Rural?}

The western coast of Asia Minor is dotted with Greek cities and major sanctuaries yet has largely been left out of discussions of 'extra-urban' shrines. At the same time this facet has been of little concern to scholars of Asia Minor. Studies of sanctuaries in this region have instead followed a very different path from those of the mainland or western Greece. Rather than their location vis-à-vis urban topography and civic territory, these shrines are usually

is the sanctuary of Zeus Chrysaoreis, of the Chrysaoric League, as one of the factors in the siting of the colony of Stratonikeia, discussed in Şahin (1976); see below in Chapter 5 .

85 Ingold (1993), (2000), (2011). Tilley's other spaces include somatic (unconscious) space, perceptual (ego-centric) space, architectural (inside-outside) space, and cognitive (theoretical, abstract) space; Tilley (1994), 16-17, also (2004).

86 It goes beyond the scope of this volume to discuss the impact of this in detail, but see the contributions in: Wescoat and Ousterhout (2012); Cusumano et al. (2013); Kristensen and Friese (2017); Friese et al. (2018 (forthcoming)). 
assessed according to their cultural or ethnic identity, specifically along an Anatolian-Greek axis. This is among others due to the availability of sources, which for a long time was largely restricted to epigraphy, falling principally within the domain of specialists. But it especially has to do with the longstanding authority of Sir William Mitchell Ramsay, who opened his 1890 work The historical geography of Asia Minor with a discussion of 'Hellenism and Orientalism' as a general principle. ${ }^{87}$ Ramsay traveled extensively and was drawn in particular to the large sacred complexes like Pessinus, the two Komanas (in Pontos and Kappadokia), and the sanctuary of Men Askaenos near Pisidian Antioch. Strabo, writing in the Augustan era, describes such cultrun 'poleis' as extremely wealthy with vast estates. ${ }^{88}$ Ramsay took this to be commonplace throughout Anatolia:

It is well known that in pre-Greek time a large part of Asia Minor was portioned out in theocracies, i.e., priest-kings representing the god, at great sanctuaries ruled over a considerable district whose population were servants and subjects of the central hieron. ${ }^{89}$

Lack of evidence notwithstanding, Ramsay's conceptualization became the prevailing model and was followed by such luminaries as Rostovtzeff and Tarn..$^{90}$ Moreover, these Anatolian independent theocracies were considered to be naturally antagonistic with the more 'secularized' Greek polis-model that overran most of the countryside by the later Hellenistic period. This

87 Ramsay (189o), 23 Part I. Ramsay's travels to Asia Minor were intended to highlight the historical inaccuracies of the Bible, which he was, however, unable to do: "I set out to look for truth on the borderland where Greece and Asia meet, and found it there. You may press the words of Luke in a degree beyond any other historian's and they stand the keenest scrutiny and the hardest treatment ..." Ramsay (1915), 89. Many see him as a protagonist of evangelical Christianity and the authority of the Bible, claims which he himself never made.

88 Strabo 12.5.3 on Pessinus: 'The priests were in ancient times potentates, I might call them, who reaped the fruits of a great priesthood, but at present the prerogatives of these have been much reduced, although the emporion still endures' (transl. H.L. Jones (1928) The geography of Strabo, LCL 211). On Strabo and the so-called temple states, see Isager (1990), 82, who discusses how Strabo's focus was the polis, and in the vast and sparsely urbanized areas of central Anatolia, these large 'states' were the closest thing to a polis that he knew.

89 Ramsay (1911), 37, the first lines of his 'Sketches in the religious antiquities of Asia Minor'; he continues, stating that it was "a necessary characteristic of such a theocracy that there should be only one centre, one hieron, one sanctuary."

$90 \quad$ E.g. Rostovtzeff (1923), and (1941), 505ff; Tarn (1931) (later revised with R.D. Griffith in 1931). The term 'temple state' is a modern concept imbued with vagaries, discussed in Isager (1990), 82-84; Sökmen (2009). 
polarization of Oriental versus Hellenizing influences underpinned academic studies of Asia Minor and was only challenged when scholars such as Louis Robert, Alfred Laumonier, Mario Segré, Franciszek Sokolowski, and Thomas Broughton began to study the epigraphic record and to better comprehend the diversity and complexity of society, institutions, and religious organization through the priesthood, sacred laws, and temple economies. ${ }^{91}$

The simplicity of Ramsay's model, however, also accounts for its tenacity. It took nearly a century before alternative and much more nuanced views of sanctuaries in Hellenistic Asia Minor began to develop, principally through the work of Pierre Debord, in his Aspects sociaux et économiques de la vie religieuse dans l'Anatolie gréco-romaine, published in $1982 .{ }^{92}$ Rejecting Ramsay's bias of ethnicity, Debord considers the organization and function of sanctuaries in nearly every regard - except religious - and, in keeping with his times, suggests that the urban-rural axis is a much more informative lens for viewing their spheres of operation. While Debord primarily takes a lateral look at shrines (as does this present study), Laura Boffo focuses on their hierarchical role as socio-political mediators between ruler and community in her thesis, Ire ellenistici e i centri religiosi dell'Asia minore, published in 1985 , only three years after Debord's. Based on Strabo and epigraphic data, she distinguishes types of shrines by their degree of autonomy. ${ }^{93}$ Autonomy is central to the third pillar discussed in this section, Beate Dignas's thesis, Economy of the sacred in Hellenistic and Roman Asia Minor, published in 2002, but she deals with this very differently than Boffo and Debord. ${ }^{94}$ Discarding their categories, she takes the view that shrines in Asia Minor had an innate authority and always operated as independent nodes within a triangular relationship that also involved cities and rulers.

Through the lens of these three major works, this section explores the different categories of sanctuaries in Asia Minor according to their geographic, social and political role, as well as their institutions and institutionally acknowledged statuses. Besides their location in civic topography, these are all relevant towards understanding the functioning of sacred centers in Greek cities in Hellenistic Asia Minor and are integral to the framework of analysis, applied throughout the rest of this volume.

91 This is just a selection of scholars and their works: e.g. Robert (1937), also (1935c); Laumonier (1958); Segré (1936) and (1948); Sokolowski's reference work on sacred laws, LSAM; and Broughton (1951); also of course Jones (1940). A good overview of this early development is given in Virgilio (1987), see also below.

92 Debord (1982) is the publication of his doctoral thesis from Besançon in 1976.

93 Boffo (1985).

94 Dignas (2002a). 


\subsubsection{Categorizing Sanctuaries in Hellenistic Asia Minor}

Pierre Debord is one of the first to holistically address religious centers in Hellenistic Asia Minor and to look beyond ethnic labels in his assessment of them. His aim is to situate religious institutions, in all their diversity, within a rational environment driven primarily by economy and social rank, but also as one that was subject to change. He continues the general line of inquiry of previous scholars, mentioned above, in focusing on aspects of trade, finances, and hierarchical organizations. ${ }^{95}$ But he clearly opposes Ramsay's polarized view of sanctuaries in Asia Minor as being either central to an indigenous theocracy or dominated by a Greek polis. ${ }^{96}$ While acknowledging the difference between Greek and non-Greek perspectives, he argues that their many forms of expression do not permit a binary division into neat silos, isolated from each other. The various local populations were probably long exposed to ideas imported from abroad, just as the Greeks in Asia Minor were themselves open to new influences that were continually changing their own constitution. This "compartmentalized mosaic" of cultures, as Debord calls it, ${ }^{97}$ thus renders any distinction meaningless that does not transcend the simple dichotomy between the (eastern) non-Greek 'temple state' complexes on the one hand and the (western) Greek polis sanctuaries on the other. He therefore introduces a third and middle category: the 'indigenous' shrines, typically the center of village clusters. ${ }^{98}$ These three categories also represent the main types of economies and social organizations, and are related to their geographical locations and degree of institutionalism, discussed further below.

This overlaps somewhat with the criteria that Boffo uses in interpreting the mediating roles of sanctuaries. ${ }^{99}$ Especially in examining dedicatory and honorific inscriptions, she highlights the appearance of keywords such as eunoia (goodwill), asylia (inviolability), ateleia (tax exemption), and eusebeia (piety) as the primary signifiers in transactions between ruler and community that

95 Summarized in Virgilio (1987), 345-350.

96 Debord (1982), Chapter 5, 'Théories antagonistiques et testimonia', 127-139. Ramsay's interpretations are now also generally dismissed in the new publications of his notebooks at the Pisidian Antioch, Ramsay et al. (2006).

97 Debord (1982), 291.

98 Debord (1982), 163-169, and somewhat reminiscent of Vallet's depiction of extra-urban sanctuaries in Magna Graecia discussed above, Vallet (1968), 89-93. A similar tri-partite division is used by Brandt (1992), 67-72, for Pamphylia and Pisidia, although his middle category includes the larger 'halbautonomer' sanctuaries located in the chora of a polis, but mostly economically independent, e.g. Apollo Didymeus, Artemis Pergaia, the Athena temple at Ilion, and Men Askaenos of Pisidian Antioch, much like Boffo's categories 5 and 6.

99 Boffo (1985) and (2003). 
were negotiated via the main sanctuary and its cult. For example, a royal grant of inviolability (asylia) for a sanctuary would typically be followed, or sometimes pre-empted, by the community's praise for the ruler's goodwill (eunoia) and piety (eusebeia), sealing the bond between both parties via the sanctuary and its cult. Rulers and communities typically relied on religion as a channel of diplomacy to secure what they needed from each other - for the ruler this was local support and loyalty, for the community royal support and protection, and for the sanctuary direct benefactions. This implies an intimate and fluid relationship between a sanctuary and its community, the one standing as symbol for the other.

In order to come to grips with the social and political significance of religious centers and how they mediated royal benefactions, Boffo distinguished nine categories of sanctuaries, depending on the organizational type of community, regional influence, and degree of political autonomy (see Table 2.1). Sanctuaries appearing in different categories underwent a transformation over the course of this period.

Of these, sanctuaries that involved a polis (category 6), are the most prominent and comprise the bulk of her work. ${ }^{100}$ Expressions of mutual goodwill were readily formulated between rulers and the local administrative bodies, the boule and demos (council and assembly), and created a moral if not juridical bond of co-commitment. The stakes were typically eleutheria (freedom) or autonomia (freedom to use own laws) in exchange for complete loyalty to the king. ${ }^{101}$ With their divine authority, sanctuaries were the ideal means of procuring both - a royal display of regard for a shrine would be met with the highest praise and honors from the associated polis. Seleukid support in rebuilding the temple of Apollo at Didyma became the binding political connection between the rulers and the city of Miletos. According to Boffo, the Seleukids were primarily interested in the renown sanctuary and its oracle, but the Milesians understood the language of diplomacy and knew how to turn this to their advantage. ${ }^{102}$

\footnotetext{
100 Boffo's chapter on 'sanctuaries associated with cities', $145^{-267}$, takes up a third of the book.

101 Eleutheria became a pivotal phrase especially in the later relationship between Rome and the Greek cities, e.g. the 'slogan of freedem', Dmitriev (2011).

102 Discussed in detail in Boffo (1985), 174-185, esp. 178-179.
} 
TABLE 2.1 Boffo's nine categories of sanctuaries in Hellenistic Asia Minor, with examples (Boffo 1985)

Boffo's categories of sanctuaries and communities, with examples

1 Grand ethno-tribal temple complexes, commonly called 'temple states'

2 Indigenous 'urbanized' sacred centers known as 'sacred cities'

3 Sacred villages (hierai komai) that evolved to urban status

4 Indigenous sanctuaries of local influence (katechon, hierai komai, those with theophoric names, or topographical epithets)

5 Temple complexes as centers of leagues, or with panegyrics, autonomous from a polis

6 Major Greek sanctuaries belonging to a Greek polis but with a degree of autonomy (cases of asylia or ateleia, or euergesia and eusebeia, etc.)

7 Religious centers reorganized by royal authority

8 Sacred centers that were incorporated into the territory of new Macedonian cities

9 Cult centers resulting from the official consecration of a city to a deity
Komana of Kappadokia and of Pontos (Ma); Zela (Anahita); Kabeira (Men Pharnakos); Pessinus (Meter/Attis); Olba (Zeus); Pisidian Antioch (Men)

Kastabala (Artemis Perasia/Kubaba); Mopsos; Metropolis (Meter)

Aphrodisias (main example) a $^{\mathrm{a}}$

Hierocaesarea; 'Attouda'; 'Apollonoshieron', 'Dioshieron'; 'Aizanoi' (Zeus); 'Astyra' (Astyrene); Larisa (Apollo

Larisenos)

Athena Ilion; Panionion; Karian leagues at Lagina (Hekate), ${ }^{\mathrm{b}}$ Panamara (koinon of the Panamareis); Hyllarima; Alabanda ('Antiocheia of the Chrysaoreis'); Labraunda; Mylasa; Lykian League at Patara (Apollo Patroos oracle); Perge (Artemis - panegyria) Sardis (Artemis); Ephesos (Artemis, Demeter Karpophoros); New Kolophon (Apollo Klaros); Priene (Athena Polias); Miletos (Apollo Didymeus); Teos (Dionysian Technitai); Magnesia on the Maeander (Artemis Leukophryene); Smyrna (Aphrodite-Stratonike; Meter Sipilene); Pergamon (Asklepios); Aigai (Apollo Chresterios); Amyzon (Artemis); Mylasa (Labraunda); Mylasa (Sinuri); Kastabos (Hemithea) Hierapolis in Phrygia (main example)

Antigonia/Alexandria Troad (Apollo Smintheus at Chrysa); Pisidian Antioch (Men); Nysa (Pluto \& Kore); Stratonikeia (Lagina-Hekate; Panamara-Zeus); Apollonia Salbake; Alabanda/Antiocheia of the Chrysaoreis (Zeus Chrysaoreus/Apollo Isotimos); Tralles (Zeus Larasios); Laodikea (Zeus 'Diospolis')

Xanthos (main example)

a The sanctuary of Athena at Ilion, in category 5, might also be included here - Debord surmises its phases, from sacred territory to sacred village, to town, and eventually to city, as typical for Asia Minor, Debord (1982), 177 .

b A better example would have been Hiera Kome near Stratonikeia, with the sanctuary of Zeus Chrysaoreus: one honorific decree by the Karian-wide Chrysaoric League was found at Lagina (I.Stratonikeia 1418), but it was not their center. 
Debord goes even further in arguing that sanctuaries were central to the process of urbanization that was brought on by rulers as they sought to create a denser structure of administrative centers in the landscape. ${ }^{103}$ This is why he maintains that the greatest bias for distinguishing sanctuaries is 'urban' versus 'rural', since sanctuaries in or near towns were most affected by 'global' ideals while those in rural areas were, in his view, generally bypassed from this evolution. ${ }^{104}$ This was not just a top-down process; at the local level it seems to have led to an internal response from communities eager to obtain royal support and regional status, as the example of Didyma shows. Reciprocity was important in the relations between the central ruler and the local community: sanctuaries were a key factor, not only as public advertising, but also for their integral value to the community. A number of stakeholders may be identified in this process. For rulers, shrines were linchpins in their "politics of fidelity"105 with the goal of establishing order and stability. ${ }^{106}$ Royal protection and economic sanctions that would be widely recognized were exchanged for the loyalty of the community, particularly in providing access to strategic places for the military but also to the sanctuary's resources (e.g. treasury) in times of need. At the other end, a community could take the initiative in securing their position with royal authorities by pro-actively issuing decrees of praise and gratitude, inducing

103 Debord (1982), 177. The polis was clearly instrumental to the success of Alexander's conquests, e.g. Fraser (1996), van Nijf (2008). See also Aperghis (2005), linking the development of Seleukid urbanization in Mesopotamia with intensified agricultural exploitation and the need for administrative centers that could handle royal monetary exchange.

104 Debord (1982), 99-100, especially in the Roman period, but also reflected in his views of Hellenistic Karia in Debord (2003) and (2005); see also Ricl on Roman Lydia and Phrygia, Ricl (2003), 79: “... a distinction should be drawn between remote rural sanctuaries frequented by villagers and functioning with the help of a modest temple personnel, and the more important and better organized sanctuaries located in close proximity to urban centres." Mastrocinque, however, interprets this on a much more general level, with the 'centripetal and centrifugal forces' of the Greek polis system which drew the significant sanctuaries into the orbit of the city, while others spun off into obscurity, Mastrocinque (1979), 216-218 (referring to Graf (1996)). Rutherford (2006) follows a similar line as he suggests that cities like Mylasa worshiped a Greek-styled Zeus while smaller villages would have continued to worship the Anatolian Tarhuntas.

105 Boffo (1985), 302, referring to Rome's recognition of the sanctuary at Panamara as $\alpha \sigma^{\circ} \lambda \alpha$

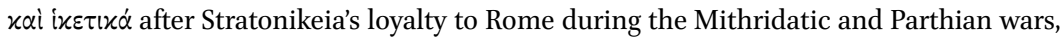
in the hymnode inscription I.Stratonikeia 1101, line 3, see Figure 5.24 and Chapter 5 , under Ritual performance at Lagina.

106 Boffo (1985), 331, citing Bickerman 1938, 133. 
concessions. This may also explain in part the progressive swing of indigenous sanctuaries and settlements towards Hellenistic forms that the rulers would be more familiar with. ${ }^{107}$ Finally, it will also have been highly important to the sanctuaries who was doing the talking for them and the degree to which their priests and personnel were involved in the negotiation processes, as they represented the direct interests of the shrine.

Beate Dignas, however, challenges assumptions of the dependency of sanctuaries in Asia Minor on civic institutions in the Hellenistic and Roman periods. In stark contrast with both Debord and Boffo, she argues instead that sanctuaries always had a strong authority of their own, even throughout these later periods. Rather than a bartering chip at the mercy of others, they formed a node of equal weight in a triangular relationship between ruler, city, and sanctuary. Her chief evidence for this is the independent, or sacred, economy of sanctuaries, which their administrators maintained by appealing directly to rulers, or to the local city as necessary. Rather than differentiating between types of shrines, Dignas stresses what they had in common. In this she leans toward the opposite end of the spectrum, treating the sanctuaries of Asia Minor across the board essentially as species of the same genus. Like Ramsay, she considers temple state sanctuaries as the extreme yet representative example of the kind of sovereignty that all sanctuaries originally possessed, independent of a separate political community or administrative center. Unlike Ramsay, however, she includes the 'Greek' sanctuaries in this monotype. ${ }^{108}$ In this she is critical of Debord's distinction and his view of 'urban' cults as completely immersed in civic life through its institutions, directed by the aristocracy (at least by the imperial period). ${ }^{109}$ On the contrary, Dignas argues that cities and cults had always operated in separate spheres, even suggesting a

107 This may also explain the early labelling as 'polis' of communities that otherwise bore none of the typical characteristics (governmental form, urban center, etc., see Mileta $(2009 \mathrm{~b})$ and $\mathrm{Ma}(2003), 38)$. Koranza is a good example, known as a polis prior to its incorporation as a deme into Stratonikeia in Karia - see Chapter 5 on the sanctuary of Hekate at Lagina (which was itself a deme of Koranza). Another is Kastabala, which outwardly took the name of Hierapolis, minted on coins of the second and first centuries BC with the title hiera kai asylos ('sacred and inviolate'), while inwardly maintaining its indigenous character; Boffo (1985), 54-6o.

108 Dignas (2002a), 224: "As far as the political and economic role of the cults is concerned, this study challenges the sharp distinction between the civic sanctuaries and the religious centres commonly labelled as indigenous, rural, or non-Hellenized." In her fourth chapter she further discusses how the different 'types' of sanctuaries fit in with her basic model.

109 Or as he calls it, "l'osmose totale entre la cité et la vie religieuse," Debord (1982), 293. 
fundamental "lack of identity" between them. ${ }^{110}$ Although she does not deny the civic dimension of sanctuaries, her own guiding bias is still 'city' versus 'cult'. Terms such as 'polis religion' or 'state cult' are problematic - the fact that the polis may have regulated one aspect of a cult does not mean they controlled all aspects, in her view, and this observation is surely correct. ${ }^{111}$ She continues to argue that shrines are natively autonomous; while in some cases they were overtaken by emerging poleis, in others they included the polis in their own expanding scope. This is what she states, for example, regarding Panamara and Stratonikeia - the evidence, however, now leans in the opposite direction. ${ }^{112}$

Dignas' study vividly highlights the generally strong economies of sanctuaries. Yet Boffo makes it clear that considering sanctuaries in Asia Minor through a single lens grossly overlooks nuances in their networks of power, administration, and community. In this she steers us far away from Ramsay's monolithic view of the 'temple state' version as the base Anatolian model. She also goes much farther than Debord in discerning the various relationships that could develop among 'indigenous' sanctuaries and their communities. This idea can, however, be taken even further: the adoption of a 'universal' language, the terminology, style and general behavior, also meant participating in a wider 'global' network of peers. ${ }^{113}$ While this is not Boffo's central research question, this is surely also what communities were after - besides good relations with rulers, they were also visibly eager to create stong ties with their peers and the wider community, facilitated by the recognition, support and concessions of the ruling forces. Having their sanctuaries declared inviolable (asylos) as 'neutral zones', sometimes even tax-exempt (through the grant of ateleia), and extending such grants to include the entire community as far as possible, opened new avenues of trade and economic advantages. At the same time, it provided the opportunity for them to host major inter-urban festivals, drawing on the wider Greek community, and thereby putting their city on the map.114

110 Instead her own study "suggests that the complete osmosis between city and religious life did not exist at any time and it emphasizes patterns of behavior illustrating a lack of identity between cities and cults," Dignas (2002a), 8 .

111 Dignas (2002a), 9-10.

112 Dignas (2002a), 243, referring to a pre-published version of van Bremen (2004b). In this article, however, van Bremen shows a strategic interest by the polis in the sanctuary, discussed at length in Chapter 6.

113 Ma (2003), 29-30; discussed in more detail below. On the homogenization of 'political culture', see van Nijf and Alston (2011).

114 The growth in panhellenic and other 'überregionaler' festivals is characteristic of the Hellenistic period, Chaniotis (1995); Parker (2004), who qualifies the term; Wiemer (2009), 117; van Nijf and Williamson (2015). 
In short, Boffo's nine categories are a prime asset in revealing the colorful diversity in the religious, social and political organization of these communities in Hellenistic Asia Minor and their relationships with their gods and their rulers. But the mechanisms of change, the shifts between categories, how local or regional 'indigenous' religious centers were turned into major civic sanctuaries, and the factor of landscape, have yet to be understood.

\subsubsection{Geography, Economy, and the Question of Sacred Lands}

Geography is a factor which Debord in particular recognizes as central to the type of sanctuary as well as its economy. He observes, as did Ramsay, that several great sanctuaries of Central and Eastern Anatolia in the Hellenistic period were located along major east-west thoroughfares and would have functioned as way-stations, or even emporia, attracting trade. ${ }^{115}$ Several were also located at political frontiers, such as Hattuša, Gordion and Sardis, connecting different regions but also attracting royal interest. The temple of Zeus at Aizanoi in Phrygia received at one time gifts (tracts of land) from both kings of neighboring Pergamon and Bithynia. ${ }^{116}$ Aizanoi itself is in a kind of frontier zone between these rivalling kingdoms and it was in their interests to win the favor of the community by investing in their sanctuary. In the west, the oracular sanctuaries of Didyma and Klaros, located along the coast, served as points of mediation for a wide range of clients. ${ }^{117}$ As with healing cults, these were specialist sanctuaries meeting universal needs and were therefore likely to be inter-urban in character and location. Indigenous federation sanctuaries also

115 Debord (1982), 10 (map), 11-18; he discusses the possible roles of merchant and artisan associations at the sanctuaries, representing commercial interests while creating a social profile at the same time.

116 MAMA IX 8, a bilingual inscription on the walls of the temple of Zeus that depicts how Hadrian restored lands once given to Zeus at Aizanoi by Attalos and Prusias, presumably Attalos I and Prusias I, Habicht (1956), 93; Laffi (1971); also Boffo (1985), 109-110 and Debord (1982), 145-146 (discussed above) who both see this as a political rivalry being played out at a sanctuary in the buffer zone of both kingdoms. Aizanoi later absorbed by Pergamon under Eumenes II and became "ein kleines Abbild Pergamons," Atik and Rheidt (2004).

117 Debord (1982), 18-22, with maps on p. 19 and 21 of the origins of clients of the oracular sanctuaries at Didyma and Klaros, respectively. Didyma, which peaked in the third to first centuries BC, generally served the Ionian coastal area, neighboring Karia, and the Milesian colonies in the Pontic and pro-Pontic regions. Klaros gained popularity in the later imperial period among the newer Roman colonies and the Hellenized cities of the interior, e.g. Phrygia, Lykaonia and Pisidia, Northern Anatolia, inner Karia, but also Thrace and Western Pontos; few coastal cities consulted the oracle. 
tended to be in 'neutral zones', usually situated in areas beyond the range of any one particular village or settlement. ${ }^{118}$

Location and accessibility of sanctuaries was clearly important in connection with festivals, particularly those with organized processions and the sacred roads that carried them. Festivals were prime outlets for commerce, especially when they were conveniently located, and under immunity. In the Hellenistic period, cities and sanctuaries went to great lengths to procure the privileges of asylia (inviolability) or ateleia (tax exemption), and to declare this publicly. This protective status surely enhanced their civic standing and expanded their wider economic impact. ${ }^{119}$ Some sanctuaries had permanent market facilities (e.g. Lagina) and acted as a sort of agora or at least a seasonal fair, occasionally with hotel facilities as well (e.g. Panamara). ${ }^{120}$ As such they were points of exchange between local and regional communities and were embedded in the economic life of the community in a symbiotic relationship.

Another economic aspect pertaining to the geography of sanctuaries is the question of sacred land, or hiera chora. A large portion of studies on sanctuaries in Asia Minor have been concerned with this aspect, and it forms a central element of Debord's thesis. ${ }^{121}$ This is also where he takes his most critical stance against Ramsay. ${ }^{122}$ As mentioned above, Ramsay believed that most of Asia Minor had once belonged to sanctuaries, each with a population that largely consisted of sacred slaves, or hierodouloi, organized in villages under the authority of priests and prophets; the Macedonian conquests brought an abrupt end to this when Hellenistic rulers brutally confiscated lands to establish new colonies. ${ }^{123}$ Jones was the first to directly oppose this view, ${ }^{124}$ observing

118 On federation sanctuaries: Debord (2003); Graninger (2011); Mackil (2013a).

119 Debord (1982), 24-25 and Boffo (1985), discussed above. Also Gluskina (1977), Rigsby (1996). This applies especially to the sanctuary of Hekate at Lagina, see below Chapter 5 .

120 On fairs and festivals, see e.g. de Ligt (1993); Chandezon (2000); Iannaconne et al. (2011); Papazardakas (2011); Frejman (2020); also for Republican Italy, García Morcillo (2013). The 'live market', or biotike agora, at Lagina is attested in the later imperial period, see Chapter 5 . Panamara was known to have lodgings for pilgrims to spend the night, see Chapter 6.

121 Debord (1982), 127-162. Sacred lands and land leasing has been the object of several studies over the last few decennia. See also: Horster (2010); Isager (1992); Chandezon (1998); Osborne (1988); van der Spek (1986); Martin (1973); and Finley (1951).

122 Ramsay (189o), generally followed by Rostovtzeff (1941) and Bickerman (1938).

123 Ramsay (189o); according to Rostovtzeff (1923), rulers saw themselves as eminent owners of all the land, sacred or otherwise.

124 Jones (1940), 309. Jones found support among Broughton ('Roman Asia Minor' in Frank et al. (1933-1940)) and Broughton (1951), Zawadzki (1952-1953), and Magie (1950). Bickerman (1938) had previously expressed his views that Seleukid rulers hardly impacted 
that rulers actually donated lands to sanctuaries on occasion, ${ }^{125}$ and that there is simply no solid evidence for large holdings of even major shrines in preMacedonian times, let alone the suggestion that this would have been commonplace for sanctuaries throughout Anatolia. Also, most of the sacred lands known to have existed appear to consist of individual, piecemeal plots rather than vast estates; they were not necessarily contiguous nor anywhere close to the sanctuary that possessed them. ${ }^{126}$ Rather than spanning across Eastern Anatolia with its 'temple states', Debord observes that most of the shrines that had sacred lands in the Hellenistic Asia Minor were actually in Karia. ${ }^{127}$ While this may result from the chance survival of documents, it may also reflect the type of holding, since the larger sanctuaries in the east presumably possessed fewer, yet more extensive, tracts of land.

The term hiera chora is usually used to refer to property belonging to a sanctuary that was commercially exploited, rather than an area that possessed some numinous quality. Besides cultivated fields it could refer to pasture, forests, even salt flats, ponds or sand pits, or areas with restricted access, sometimes allowed only for the herds of animals belonging to the sanctuary. ${ }^{128}$ Debord's three categories of sanctuaries also have correspondingly different uses of sacred lands. ${ }^{129}$ The great eastern 'temple states' were presumably worked by thousands of hierodoulo $i{ }^{130}$ whereas the smaller 'indigenous'

the existing feudal structure. Robert and Robert (1954), 231-232 took a slightly more nuanced position based on Apollonia Salbake, believing that the Seleukids did control the revenues of sacred villages which in turn resisted them; see below.

125 As at Aizanoi, MAMA IX 8. The governor Olympichos dedicated some of his personal holdings, which had been royal gifts, to the sanctuary of Zeus Osogollis at Mylasa, discussed in Chapter 3 .

126 Occasionally temple funds were used by a city or association to purchase tribal lands, Debord (1982), 130, discussing Jones (1940), 309. This certainly coincides with the picture from the documents at Labraunda and Mylasa, listing and describing the individual tracts of property that were sold or donated to sanctuaries, and the lands adjacent to them, see Chapter 3 .

127 Debord (1982), 137-139; Pernin (2014). See also below.

128 Debord (1982), 170, e.g. most sanctuaries had a sacred wood, or hieron alsos, p. 170 n. 59. On restricted access around the marginal areas around sanctuaries, see McInerney (2006). See also Cazanove and Scheid (1993); Ampolo (1993); Jacob (1993); Bonnechere (2007).

129 Debord (1982), 163-169, following Robert and Robert (1954), 295 and recognizes with them the wide range of variations among sanctuaries, according to region and situation.

130 E.g. the hiera chora of Pontic Komana was known for its vineyards, Strabo 12.3.36. An exception is Pessinus, the only temple state with no clear indication of sacred lands. 
sanctuaries, associated with villages or federations (koina), probably held sacred lands as common property, e.g. the Pormounos kinship group (syngeneia) that administered the sanctuary of Sinuri. ${ }^{131}$ Finally, sacred lands belonging to the more Hellenistic civic-oriented sanctuaries were generally administered by the polis rather than the clergy directly; Debord believes this to be the base of the conflict between Mylasa and the priest Korris at Labraunda, discussed in Chapter $3 \cdot{ }^{132}$

Sacred land leases are particularly well documented in the second century вС in the area around Mylasa in Karia, and Dignas uses the conflict between Labraunda and Mylasa to substantiate her main argument on the general autonomy of sanctuaries. ${ }^{133}$ The area of Mylasa exercised a unique construction of hereditary leasing where the seller and his heirs transferred their property to the god, but immediately rented it back and exploited the land under a very low rate of rent. While not uncommon in the Greek world, especially Delos, the land-lease documents from Karia and specially the area of Mylasa represent the largest corpus of transactions of sacred property. ${ }^{134}$ Besides Mylasa, they stem from the nearby communities of Olymos, Hydai, and the sanctuaries of Sinuri and Zeus Labraundos, all of which had been absorbed by Mylasa by the end of the third century вс. ${ }^{135}$ The transactions consist of the proposal by the owner, the purchase by the shrine, and the leasing of the land back to the original owners and his heirs. ${ }^{136}$ Why this practice suddenly surged in the second century BC is debated. Dignas argues that this was an act of piety, to ensure an income for the gods that could only be secured through sacred lands, while providing ready cash against low rent for the lessee. ${ }^{137}$ In

131 Debord uses Lydian Katekaukemene as an example, showing how the land was owned by the community, with the god as patron, Debord (1982), 174-175. At the sanctuary of Sinuri, the land is seen to belong to both the god and the syngeneia of Pormounos, see below Chapter 4.

132 See Debord (1982), 169 and (2011), and below in Chapter 3 .

133 Dignas (2002a), 95-106; also Carless Unwin and Henry (2016), van Bremen (2016). These are discussed in more detail in connection with Labraunda, Chapter 3 , and the sanctuary of Sinuri, Chapter 4.

134 See Isabelle Pernin's corpus, Pernin (2014); Dignas (2002a), 96; Debord (1982), 154 and 158, further discusses tenant farming on sacred lands around Ephesos, Halikarnassos, and Aphrodisias.

135 Gary Reger suggested a higher date, relating it to coinage that was compatible with Rhodian standards, in Ashton and Reger (2006), 125-132.

136 Described in detail in Debord (1982), 169; Dignas (2000) and (2002a), 92; Chandezon (2003), 240-241; and now Pernin (2014), 401-455, esp. 422-427.

137 Dignas (2002a), 104. On p. 24 she demonstrates the sellers' obvious personal gain, but later states that this was only a by-product; the true motivation was "a combination of piety and atavism." Also Dignas (2000) and (2002a), 99-102. 
her view, the gods were the primary beneficiaries of this practice that guaranteed a steady budget for festivals and regular sacred activities. Debord sees parallels in the medieval period, when land was placed in divine hands for protection especially in times of risk, justifying the low rate. ${ }^{138}$ Raymond Descat and Isabelle Pernin suggest a direct link between the release from the control of Antiochos III, enforced by Rome, and new economic opportunities. ${ }^{139}$ Sacred lands could enjoy a special, protected status that private properties did not have, as the example of the lands at Sinuri will show. ${ }^{140}$ In any event, the hereditary construction of the leases will also have played a large factor in their emergence in the first place.

In contrast with Western Greece and the mainland, the geography of sanctuaries in Asia Minor has largely been analyzed from an economic perspective, taking the role of sacred lands as point of departure. Much work remains to be done in placing the sanctuary within its social and political geography. Boffo's categories can be useful in this regard, e.g. the connection between local settlement, federated cities, or urban center. For example, the term katoikoi, used in various contexts for those dwelling in or near the sanctuary, relates to the social geography of shrines. This term could indicate rural communities that settled in sacred villages, or hiera komai, as in Boffo's categories 3 and especially 4, also attested at the sanctuary of Sinuri. ${ }^{141}$ Katoikoi can also designate communities in close contact with developing cities but not yet absorbed by them, as with the sacred villages that came into conflict with Apollonia Salbake (Boffo's category 8). ${ }^{142}$ Finally, katoikoi may also imply full-fledged citizens who live

\footnotetext{
138 Debord (1982), 169 and later Descat and Pernin (2008) and Virgilio (2010).

139 Descat and Pernin (2008).

140 See the discussion in Chapter 4 of the land-lease construction of Sinuri after the violation of lands by the troops of Antiochos III. This shows the vulnerability of such lands in troubled times.

141 See Debord (1982), 90-92; Boffo (1985), discussed above. Hiera Kome is also the name of the community (turned deme) at the site of Stratonikeia, probably for the sanctuary of Zeus Chrysaoreus, see Chapter 5 below.

142 Two sacred villages of the Saleioi (one in the mountains, the other in the plains) revolted against the new polis of Apollonia Salbake; the nature of the conflict is unclear, but it escalated enough to require royal intervention, as at Labraunda: discussed in Debord (1982), 147-148, who also refers to the sensitive analysis of Apollonia Salbake Robert and Robert (1954), 231-312, relating its foundation to the geography of the area. Boffo includes Lagina in this category, yet the katoikoi do not appear until the imperial period; they issued certain honorific decrees together with the demos and boule, and so might appear to have been a parallel organization, but the same may be said of the gerousia at Stratonikeia, see below in Chapter 5 .
} 
elsewhere, as at Labraunda where the local residents of the sanctuary were considered citizens of Mylasa. ${ }^{143}$

The economic role that these sanctuaries had was clearly important, but not their only drawing card. Their symbolic role within the landscape was surely just as important in their new political role as anchors in civic territory. Debord's urban-rural dichotomy, while indeed taking us beyond non-informative questions of ethnicity, meanwhile imposes a new modern polarity on the social landscape, the problems of which are discussed above. It furthermore introduces the problem of how to assess the many sanctuaries located at points far beyond the urban centers, sometimes in very rural areas, that were nonetheless critical to the process of urbanization. ${ }^{144}$ Focusing instead on the nature of the relationship with the polis, as Attilio Mastrocinque has done, could be more productive. ${ }^{145}$ In many cases older 'rural' sanctuaries were highly instrumental in alleviating tensions that might otherwise have arisen in the composite community of a new polis; such cults offered a central focus and common identity, while simultaneously imbuing a sense of shared territory. These issues are addressed in this present research, which also considers aspects such as ritual performance and visual associations that Debord intentionally excluded from his already broad focus, yet which are vital towards understanding the success of this relationship.

\subsubsection{Priesthoods and Sanctuary Administration}

A final concern that studies of sanctuaries in Asia Minor often address is the way in which they were administered and their degree institutionalism, revolving on the role of the priest. ${ }^{146}$ As Debord argues, this position was the hinge between the sanctuary, society and the authorities. He distinguishes priesthoods through two "diametrically opposed poles": the 'Greek' magistrate acting on behalf of the city in an elected position, versus the 'indigenous' priest,

\footnotetext{
143 Discussed below in Chapter 3.

144 See the map in Figure 1.1, in the Introduction, and the list of cities in Table 1.1.

145 In a discussion on the centripetal/centrifugal forces of the polis in Hellenistic Karia and Ionia, Mastrocinque observes that the more successful sanctuaries were those that were drawn into the orbit of the city, while the more recalcitrant were flung aside (e.g. the sacred villages of the Saleioi at Apollonia Salbake), Mastrocinque (1979), 216-218.

146 E.g. the contributions in Horster and Klöckner (2011) and Horster and Klöckner (2013).
} 
who is absolute master of the domain and occupies the function for life. ${ }^{147}$ The line between these two poles, however, was anything but clear and there were many variations between. ${ }^{148}$ Nonetheless, Debord focuses on the distinction between the two types, arguing that since the 'indigenous' priests would have had greater autonomy, and more privileges, they also would have offered the most resistance to the processes of Hellenism. In his view, the position of the 'indigenous' semi-autonomous clergy began to crumble after the Macedonian conquests, along with the political system, eventually making way for the institutionally based installment of the office of priesthood via the polis. ${ }^{149}$ This contrast informs Debord's discussion of the controversial priesthood at Labraunda, which went from a hereditary office (i.e. 'indigenous' in Debord's scheme) to one that was elective and annual (i.e. 'Greek'), at least by the first century вС if not before. In his 1982 volume he saw this conflict, a dispute between the priest and the polis over control of the sacred lands of the shrine, in the same light as the revolt of the sacred villages against Apollonia Salbake - both extreme examples of the path taken at several 'indigenous' sanctuaries as they were absorbed into the system of the 'Greek' polis. ${ }^{150}$ In a later publication, Debord considers Labraunda to be more of an isolated and complex case. ${ }^{151}$

The office of priesthood is the second prong of Dignas' argument for the autonomy of sanctuaries, with the same Labraunda conflict as her archetypal example. Dignas takes the direct access which the priests at Labraunda had to the kings in their appeal as evidence for their sovereignty. ${ }^{152}$ She also views it as proof of the inherent tensions between an autonomous community focused on a sacred center governed by priests, and the system of distributed power

147 Debord (1982), 52 .

148 Debord (1982), 51-75 discusses the priesthood. He observes that you could not draw a line between a Greek coastal fringe and an indigenous interior; the adoption of Greek names by indigenous priests is an example, Debord (1982), 51. The list of priests at Sinuri illustrates this shift later in the second century вС, see Chapter 4. However, the use of Greek names in local populations was a widespread phenomenon, e.g. Piras (2010); Aubriet (2013).

149 Debord (1982), 54 and 263-293 for a sketch of the attitudes of temporal powers towards local sanctuaries.

150 Debord (1982), 51-53.

151 Debord (2011), further discussed in Chapter 3 below.

152 Dignas 2002, 59-66: "kings as mediators," and 95-96. In the first conflict, the priest Korris appeals directly to Seleukos II, I.Labraunda 1 and 3 . 
modeled on the Greek polis, where the principal authority is the boule and demos. For Dignas, it is no wonder that conflicts arose in areas where cities exercised increasing power over local sanctuaries, as at Mylasa and Apollonia Salbake; given the widely differing systems, this would have been the norm..$^{153}$ Yet if this were the case, such conflicts should have been more common. As it stands, these are the only two examples currently known from all of Hellenistic Asia Minor. ${ }^{154}$ The lack of evidence may well be due to the need by the polis to present a harmonious picture, as Dignas argues, ${ }^{155}$ but presuming an underlying current in the exact opposite direction when there is no corroborating evidence is very tenuous.

The studies by Debord and Dignas have elucidated several important aspects about priesthoods in Hellenistic Asia Minor regarding the authority of the office. Ongoing work, however, has shown that these offices, like the cults which they serve, are too varied to be divided along axes of 'indigenous' versus 'Greek', or 'urban' versus 'rural' in any satisfying way. ${ }^{156}$ More interesting is the common language that was being developed across the board as a wide variety of sanctuaries were being harnassed to civic identities. The nature of priesthood is a touchstone for the degree to which a shrine is integrated with civic institutions, but it should also be considered within the overall context of its cult, along with its shrine, its festivals and rituals, and especially the social fabric that supported it.

153 Discussed in Debord (1982), 147-148, Robert and Robert (1954), 231-312. Dignas uses both cases to support her argument of the general independence and authority of sanctuaries and their priests, Dignas (2002a), 67-69, discussed below; these both seem to be highly exceptional cases, however, and it is difficult to see how representative they might have been of a wider undercurrent.

154 Debord also notes the potential for clashes with the Greek system of administration, but views these cases as exceptions to the rule of harmonious transitions rather than indicative of a wider trend, Debord (2011), 144-145.

155 Dignas 2002, 69; see also Alcock (2002), 23: "Such texts [literary and epigraphic evidence CGW] best illustrate dominant commemorative narratives, and it is rare for them to offer alternative versions or a glimpse into the potential range of counter-memories."

156 See especially the contributions in Horster and Klöckner (2011) and (2013); Dignas and Trampedach (2008). Also Meier (2012) in connection with construction activities. 


\subsection{Reflection}

Studies of shrines in Hellenistic Asia Minor have long been dominated by the ethnic bias, yet these more recent approaches show that the impact of urbanization and the model of the polis had far-reaching consequences. Debord uses the urban-rural bias to explain the growing political significance of polisoriented sanctuaries while Boffo sees this as only one of many types of cult organization in Asia Minor, albeit one which obviously gained traction; Dignas focuses on the tension between city and sanctuary. As comprehensive as they are, none of these studies investigates the role of civic landscape or ritual space. Debord's axis actually stresses a divide between the urban and the rural, even though models developed for Archaic and Classical Greece show that both areas were vital to the polis. At the same time, however, even these models reinforce the distinction by simply classifying sanctuaries according to their distance from the urban core, e.g. 'extra-mural' and 'extra-urban'. Such categories can reveal spatial patterns, yet obscure the implication of other factors, as with community type in Boffo's classification. Also, mapping these spatial categories onto psychological traits affiliated with the Greek pantheon presumes a degree of coherence that was simply not the case in Hellenistic Asia Minor, where the polis model was usually imposed upon a mosaic of pre-organized communities. The core-periphery model that underlies the urban-rural bias is good for studying the impact of new centers in existing landscapes, but is poorly equipped for understanding how they brought communities together or what their position was in the urbanizing world.

Nonetheless, these approaches taken together show a number of issues to watch for when studying the phenomenon of the absorption of country sanctuaries by rising poleis. Besides the spatial location with regard to the town center, we need to take into account their 'urban rituals', e.g. festivals and processions, the scope of their festivals, their economies, their administration and nature of priesthoods, degrees of autonomy, and their symbolic power. These also need to be understood within their spatial and social environments, not only with respect to the urban center and the border, but also with local settlements, other shrines, tombs, or fortifications. In this study the modern line between urban and non-urban, or extra-urban is intentionally blurred. Moreover, these 'urban rituals' should be assessed from the perspective of movement through their landscapes/civic territory - what local features, communities, or economic zones were connected through sacred routes, and how was this experienced, by whom? All of these are potential indicators of their incorporation in the institutional framework of the polis.

Rather than impose yet another blanket model on country sanctuaries, it is important to examine the data from a closer point of view. Political status, 
territorial integrity, and economic gain were just as critical to developing poleis in Hellenistic Asia Minor as they were in Archaic and Classical Greece, but the context was different. Cities were shaped out of composite communities, and internal social cohesion and urban integration were as much at stake as external political boundaries. In order to understand these processes, one must also understand how space affects the social and political condition, not only by drawing centers and borders, but by understanding how these sanctuaries and their landscapes could invoke a 'sense of place' and belonging on the inside, while offering a perspective on the outer world. Such a comprehensive view calls for an approach that transcends the disciplinary boundaries applied until now, and applying theories that can accommodate the fuller contexts of these special places.

\section{Approaches from Outside the Box}

The gap concerning studies of the urbanizing role of country sanctuaries is due in part to the nature of the data and the specialisms required in their analyses. The 'extra-urban' sanctuaries of Archaic and Classical Greece, evidenced by their material culture, are largely discussed by archaeologists, whereas the religious centers of Asia Minor, with their epigraphic records, have long been the domain of ancient historians. As we have seen, however, both approaches leave several important questions unanswered. It remains to be understood what the role of sanctuaries was in turning sacred landscape into political territory, beyond (possibly) defining its borders. How was the environment perceived at a sacred level, and how might sanctuaries have helped realign local memories to the new situation? Enough studies deal with ritual as a producer of hierarchy, but was the distance between the political and sacred centers also effective in forging a sense of community? What impact did these country sanctuaries have on the new social structure? Regarding the new political world, what mediatory role was fulfilled by these sanctuaries, and what kinds of wider networks did they address? In what ways did they serve to create a central identity and channel of community pride for their cities? Besides synthesizing current approaches, this research also turns to alternative avenues in addressing these questions. This section discusses processes of spatial memory and 'mental mapping', the general role of ritual in the development of social cohesion, the importance of local and 'global' networks, and the establishment of regional identity as promising directions, drawn from the social and spatial sciences, that can shed bring new perspectives on interpreting the many 
layers that together shaped the bond between a developing city and a distant sanctuary.

\subsection{Spatial Memory and Visual Regions}

Before we can interpret changes in the configuration of political territories, and the gravitational pull of rising urban centers on established sacred and economic landscapes, it is necessary to understand how the human mind conceptualizes space as it is processed through memory. How landscape is experienced and especially recalled, and how these memories may be guided by significance of place is one of the objects of study in the spatial sciences. The term 'mental map' is often used to refer to an individual's perception of the world. ${ }^{157}$ In psychology, this idea, more commonly known as 'cognitive map', 158 extends to include the construction of spatial memories in the human brain. Barbara Tversky observed that a much better metaphor is 'cognitive collage' as it does justice to "the complexity and richness of environmental knowledge," whereas the word 'map' implies a false degree of metrical accuracy. ${ }^{159}$ Instead of distances, the human brain remembers space through 'mental snapshots' of single views, making new snapshots as the perspective shifts, but also combining this with other 'memory snippets' of spatial information. ${ }^{160}$ This makes for a haphazard collection of mental material that people use to recall places or give directions. While this applies to the modern era, it seems especially appropriate in a world that was navigated largely without the aid of cartography. ${ }^{161}$

157 There is no room here to go into the plethora of usages of the terms 'mental maps' or 'cognitive maps'. A good overview, however, may be found in Langenohl (2005) and especially Portugali (1996). See also the 'Common Sense Geography' construction of historical spatial memory through ancient texts, Geus and Thiering (2014).

$15^{8}$ First introduced by Tolman (1948) in his article 'Cognitive maps in rats and men'.

159 Tversky (1993), 21. Tversky's work focuses on the linguistic representations of space. On the different approaches between 'image' and 'map', see also Hirsch (1995), 16-21. Here I discuss the subconscious perception of space, rather than formal representations, which for navigation in antiquity often took the form of lists or itineraries, see e.g. Salway (2001); Talbert and Brodersen (2004); Warburton (2017 (2018)).

16o Tversky (1993), 15 and 21. 'Memory snippets' can be real or imagined, e.g. known travel times, second-hand directions, historical events known to have taken place, local legends, etc.

161 See also Fehr (1970), 54: "Der antike Mensch fasste seine Umwelt nicht als ein unbegrenztes Raumkontinuum auf, sondern orientierte sich im Sinne einer 'körperräumlichen' Vorstellung an den Einzelgegenständen und Geländeflächen seiner Umgebung." 
All of the senses are engaged in navigating one's way through the world, yet vision occupies a special place in acquiring knowledge over great distances. ${ }^{162}$ As Tversky observed, the brain organizes its environment through visual memories, mental snapshots. Colin Ellard calls this visual 'regionalization', or more simply, 'chunking space.'163 Because features that occur within a single view are remembered together, they are mentally grouped together and so 'feel' nearer than features that are not in view. This perceived closeness makes the environment much more comprehensible, although it has very little to do with actual metrical distance. ${ }^{164}$ In a sense, space is collapsed between features that are 'chunked together' in this way. Tversky furthermore observed that "people judge the distance from an ordinary building to a landmark to be smaller than from a landmark to an ordinary building." 165 Hirsch refers to ways that such familiar or renown places, especially of intensive regular activity but also stories, are 'foregrounded' against a 'background' of possibilities. ${ }^{166}$ These metaphors emphasize the kind of foreshortening that takes place in the mind's eye as such localities of significance are brought into higher resolution. Places of meaning are foregrounded and therefore serve to structure mental maps.

Sanctuaries obviously fulfilled this position, especially when they could be seen from a distance, as with Labraunda that commands the plain of Mylasa. But connecting routes are also important as they would produce a series of mental snapshots, one taken at every turn, that are later sequentially stitched together by the brain. The result would be an expanded 'visual region', with one snapshot flowing over into the next as the route is recalled. In this respect, processions played an equally important role in not just connecting city and sanctuary, but in collapsing the space in between. This closeness would have been intensified with every stop along the way - at shrines, altars, tombs, but also springs, trees and other resting points - and every repetition of the

162 Llobera (2007) and Wheatley (2014) address the dismissal of the 'primacy of vision' in contexts advocating a more holistic sensorial approach. Some studies on the referential role of the senses in general: Butler and Purves (2013); Hamilakis (2014); Toner (2016); Betts (2017).

163 Ellard (2009), 126-128.

164 Ellard (2009), 126-128; Tversky (1993), 15-16.

165 Tversky (1993), 18, drawing from Sadalla et al. (1980) on reference points and perceived relationships between them.

166 Hirsch (1995), esp. 4-6, 22-23; similar to Lynch's distinction between nodes and landmarks, Lynch (1960), 47-48. The concept is further developed by Stewart et al. (2004), 184 and 206, who consider caribou crossings as 'foregrounded' places in the Inuit perception of landscape. Price (2012), on myth as a way of foregrounding places. Williamson (2016b) on foregrounding places in the landscape of Pergamon. See also the role of skill and 'taskcapes' in Ingold (1993) and (2000). 
ceremony ensured that the space between was mentally 'chunked', merging the vistas along the twists and turns into one comprehensive unit of space. Understanding these stops as familiar anchors of reference adds a new dimension to their importance.

These anchors are crucial to the composition of a visual region, and hence to the formation of a sense of territory. Technically a visual region is similar to what is known in archaeology and geography studies as a 'viewshed', a map of the extent of visibility from one or more vantage points. A viewshed is also known as an 'isovist', or 'isovist field', although these terms are more often used in urban or architectural design to refer to the shape or volume of the viewshed. ${ }^{167}$ Isovists provide units of spatial analysis used in modeling human circulation; it has been shown, for example, that popular isovists are not necessarily those which provide the largest viewshed, but those that connect two or more viewsheds. ${ }^{168}$ This helps explain why so many decrees were set up in or near gateways, e.g. at Labraunda, the sanctuary of Sinuri, and at Lagina. Transitional zones offer the greatest potential for action and this is where people tend to linger. Besides landmarks, such spatial 'hinges' also served as visual anchors that linked mental snapshots together and directed human movement.

Spatial syntax deals with types of space and their sequences. Kevin Lynch's definition of paths, edges, districts, nodes, and landmarks as the basic elements of the city is still a reference point for studies on urban space. ${ }^{169}$ Of these, especially paths and nodes describe different kinds of human movement. Paths are linear routes representing movement, ${ }^{170}$ and ways to get to nodes, places of activity or "where things happen."171 Although developed for the urban environment, this movement-stasis paradigm can be applied to any context of travel and destination, such as the contrast in sacred space between processional routes as paths of movement, and sanctuaries as nodes of activity.

I use the term concentric space to signify nodes as delimited ritual space with a static focus and an inward-facing character, directed towards a central ritual action or performance such as a sacrifice, contests or banqueting. As enclosed

167 Benedikt (1979): "An isovist is the set of all points visible from a given vantage point in space and with respect to an environment."

168 Readinger (2002). Isovist analyses were applied to the Tate Gallery in London to analyze the circulation and predict bottlenecks, many of which were at entryways, see Batty (2001).

169 Lynch (1960), 46-83; discussed in Ellard (2009), 196 as elements that also help us remember space.

170 Lynch (1960), 47: "people observe the city while moving through it."

171 Ellard (2009), 196, on nodes. 
yet spacious areas, capable of accommodating a large gathering, their isovists typically have a relatively even open shape. Such concentric spaces correspond with the idea of social space, "the nucleus for the establishment of an endless number of culturally specific orders and relations,"172 i.e. a place where people go to spend time together. This kind of concentric space, full of intensive activity, emotions, memories, and traditions, is surely 'foregrounded' in the mental organization of geography. ${ }^{173}$

Furthermore, I use the term linear space to represent 'paths' with a moving focus that successively connect places, functioning as the spatial 'hinges' discussed above. This can be either kinetic, such as sacred roads as the vehicle of processions, or visual, through sightlines, in which only the eye progresses from one point to the next, creating an immediate association among the features within its scope. ${ }^{174}$ Just as physical paths provide real access to distant targets, these visual paths work to compress the perception of space, bringing the objects within view into a close and comprehensive visual region, as discussed above. Examples may be found at Labraunda, where the sacred road serves as kinetic linear space, bringing processions from the city, while visual linear space is represented by sightlines towards Mylasa and across southern Karia, framed in the windows of the andrones at the sanctuary. ${ }^{175}$ Either way, linear space has much more to do what Tim Ingold describes as wayfaring, and the "intimate bond that, in wayfaring, couples locomotion and perception."176 Rather than just moving from A to B, travelers by eye or by foot are closely observing the environment and looking for signs of places to rest, to worship, and to remember.

Fehr describes visual linear space with regard to ancient 'platforms', or terrace architecture, and the deliberate exploitation of views. Such vistas over majestic landscapes gave rulers a sense of total control. ${ }^{177}$ Certain parts of the landscape, however, could also visually be isolated by 'framing' them, for

172 Summers (2003), 117, on enclosed architectural space as social space.

173 For a modern parallel, see Setha Low's vibrant observations of plazas in Latin America, Low (2000).

174 See also Summers (2003), 157-159 on paths as connectors. The importance of embodied ritual movement is especially stressed in Connerton (1989), h. 3, and Connelly (2011).

175 Discussed in more detail in Chapter 3; also Williamson (2014c).

176 Ingold (2016 [2007]), 81 .

177 Fehr (1970), 49: "Das Machtgefühl des Großkonigs angesichts des sich zu seinen Füßen ausbreitenden Geländes läßt sich vor dem Hintergrund jenes Herrschaftsanspruches über die Natur selbst ohne weiteres begreifen," in discussing Darius's battle against the Skythians in Pontos. Tuan (1977), 38-40, discusses the need to command visual space as connected with power: "Modern nations like to think that a high peak, if not the world's highest, lies within their border," p. 40. Further discussed in Williamson (in press-a). 
example through stoa architecture but also through the use of windows and doors that direct an axis between the viewer and the target of vision. Fehr interprets such visual axes as being closer to the Roman perception of space, ${ }^{178}$ but the connection with temple orientation, commonly towards the sunrise or some other astronomical phenomenon was also intrinsic to Greek architectural principles. ${ }^{179}$ The intentional framing of a view across the landscape takes shape in the Hellenistic period, and Fehr traces this back from Pergamon to Late Classical Labraunda. ${ }^{180}$ The southeast axis of the temple and altar of Meter Theon at Mamurt Kale was observed by its excavators to be perfectly aligned with the temple of Athena on the akropolis of Pergamon thirty kilometers away, and beyond that another six kilometers to the sanctuary of Meter at Kapıkaya; some believe that the gaps between temple and stoa on either side frame this view. ${ }^{181}$ Kinetic and visual linear space could both be used to foreground remote places of significance, and thus collapse the distance in between.

${ }_{17}$ He bases this largely on the linguistic difference between the Greek and Latin words $\delta \dot{\alpha}$ $\varphi \alpha \sigma \iota \varsigma$ and prospectus; $\delta \dot{\alpha}^{\prime} \varphi \alpha \sigma \iota \varsigma$, from $\delta \iota \alpha \alpha i v \omega$, to appear or shine through, emphasizes the target of vision as subject, impressing itself upon the passive viewer, whereas the word prospectus, from prospicio, to look outward, implies the viewer as subject, actively creating the visual axis (Blickachse), since he or she is the one doing the looking out from the architecture, Fehr (1970), $5^{6-58}$, and 61, with an extensive discussion on $\delta$ í่ $\varphi \alpha \sigma \iota \varsigma$ on p. $5^{8} \mathrm{n}$. 139. See also a building inscription from Iasos, I.Iasos 22, lines 9-11: $\tau \dot{\alpha} \varsigma \delta 1 \alpha-\mid \varphi \dot{\alpha} \sigma \varepsilon 1 \varsigma$ $\tau \hat{\omega} \nu \sigma \tau \nu \lambda \circ \pi \alpha \rho \alpha \sigma-\mid \tau \dot{\alpha} \delta \omega \nu$ (date unknown).

179 Dinsmoor (1939); now Boutsikas (2009) and (2015); Boutsikas and Ruggles (2011).

180 Fehr (1970), 'Plattform und Blickbasis', Pergamon and Labraunda are discussed in p. ${ }^{2-39}$. Fehr draws on Martin (1951), 147 and (1974), who ascribes this to Persian influence transferred to Karia through the Hekatomnid satraps; Pedersen (2004), 429. Another example is the platform of the Hellenistic temple of Athena in Ilion that included a peristyle courtyard left open on the north side, presumably to view the plain of Troy, Rose (2012). An earlier example, however, may be found in the fifth century propylaia on the akropolis in Athens, interpreted in Martin-McAuliffe and Papadopoulos (2012) as framing the view to Salamis. For the Roman period, see also the concept of 'urban armature' as developed by MacDonald (1986), using similar principles to describe the axial directionality of colonnaded streets.

181 Conze and Schazmann (1911); Nohlen and Radt (1978), 71. Further addressed by Schalles (1985), 27, in discussing the expansion of the sanctuary by Philetairos: "Diese Sichtverbindung [between sanctuary and Pergamon - CGW] wurde durch die Neubebauung nicht nur nicht eingeschränkt, sondern für den Besucher des Tempelvorplatzes durch flankierende Hallenbauten eher hervorgehoben. Zwischen diesen und dem Tempel verblieben einige wenige Meter Zwischenraum, dem Schutz vor der oftmals rauhen Witterung gewiss nicht dienlich, aber ein wirkungsvoller architektonischer Rahmen für den Blick des Pilgers auf den Burgberg." For the implications of this axis, see Wulf (1999), 41, also Williamson (2014a). 
The importance of the spatial dimension is especially clear when we consider that the human mind thinks, and particularly remembers, in terms of space. Robert McCauley and Thomas Lawson call this 'situated cognizing', meaning that our physical environment triggers our thoughts and produces memories and associations through spatial orientation. ${ }^{182}$ Memory resides in places but it is its tangibility that causes it to surface. This partly explains why not only monuments, but also landscapes and the places they connect are so powerful to group identity. Maurice Halbwachs stated as much in his seminal work On collective memory: "If a truth is to be settled in the memory of a group it needs to be presented in the concrete form of an event, of a personality, or of a locality."183 Monuments and rituals create 'collective memories' by intention. They are among the many varieties of the 'lieux de mémoire' that anchor social memory to key locations, particularly in times of rupture as Nora argues. ${ }^{184}$ The effect is accelerated when such places are infused with ritual performance, inherent mnemonic instruments of repetition and spectacle. The question, of course, is whose memories are being promoted to the collective consciousness and whose are being brushed aside with the creation of these monuments and ceremonies. ${ }^{185}$

Ritual space reinforces memory. Performing rituals in concentric or linear space creates a stack of memories that tie these events and all the corresponding associations to the specific places in which they occur. The processional routes that were ritually traversed year after year served to embed the landscape into the spatial 'cognitive collages' of the community as did the memorable features along the way, e.g. the altars, villages, tombs, trees, and springs. The personal stories that would have accumulated during these processions and festivals helped turn the environment between the city and the sanctuary into a 'memorial landscape' for everyone who was involved. ${ }^{186}$ Echoes of

182 McCauley and Lawson 2007, 213-214. They note for example that dementia is greatly accelerated or even induced when elderly people are moved from a familiar environment into a foreign one.

183 Halbwachs (1992), 200, in discussing the sacred topography of Jerusalem; cited in Alcock (2002), 25, who views Halbwachs as an early "mnemoarchaeologist." Architectural space was a powerful mnemonic aid for rhetorical speeches, as described by Simonides, discussed in wonderful detail in Yates (1966).

184 Pierre Nora's concept of 'lieux de memoire' was developed with regard to the role of landscape and 'place' in the history of France and the paradoxical need for tangible memories in an amnemonic society, Nora (1984-1992).

185 Sue Alcock addresses this in her discussion of the archaeology of memory, Alcock (2002), 15-23; also the introduction of Van Dyke and Alcock (2003), 1-13, esp. 3-6.

186 Dwyer and Alderman (2008), 173-174: "It is not just that these performances happen in or at places of memory. Rather, the memorial landscape is constituted, shaped, and made 
violence underlie this concept, ${ }^{187}$ yet while this was certainly a factor, it was much as anything the way that personal experience was interwoven with collective ritual action that gradually etched the habitual memory of the city into the landscape, making the sacred route a 'lieu de memoire' in the broadest sense. ${ }^{188}$

The same dynamics may be applied to the space at the sanctuary, although here the enclosed concentric spaces made excellent arenas for the top-down engineering of collective memories. Besides the sacrifices and feasting, this is often where individuals were honored, and where the important political or communal events were commemorated in stone, or with statues. In this sense, these concentric spaces served as 'memory theaters', preserving and perpetuating a particular view of the community through these monuments. 189 These were the mnemonic devices that are part of the mechanisms of urban identity and were therefore typically set up in the 'most conspicuous place' in the sanctuary; ${ }^{190}$ their carefully chosen locations reveal the critical spots in ritual space.

Country sanctuaries, with their often spectacular views, were undergoing significant changes. Their natural visual regions now encompassed and helped compress political territory. Their sacred spaces could be exploited to emphasize this facet, whether linear, through processions or visual connectivity, or concentric, through new rituals that focused on the polis. A grand investment in place-making on a large scale was in progress that turned local or regional shrines into warehouses of urban memory, transformed by ritual and its residue.

important through the bodily performance and display of collective memories." Price (2012) on myth, memory, and place.

187 Alcock (2002), 19-21 on 'disturbing memories'. Lagina, Panamara, Labraunda and the sanctuary of Sinuri were all involved to some degree in the turmoils of the third to first centuries BC, discussed in the case studies below.

188 Connelly (2011); Chaniotis (1995) and (2013). Also Chaniotis (2006) on the emotional dimension of rituals.

189 Such monuments are the 'durable, inscribed' type, discussed in Alcock (2002), 28; see also Dwyer and Alderman (2008). Pontus Hellström considers Labraunda in the Hellenistic period as a 'Memory Theater', referring to an intentional preservation of the dramatic Hekatomnid state of the sanctuary, Hellström (2009), 278-279, discussed further below in Chapter 3. See also Samuel (1994) on the importance of place as a mnemonic device. Marietta Horster discusses the Eleusinian as a place of 'corporate memory' through inscribed monuments, Horster (2013).

190 The epiphanestatos topos, or the most conspicuous place, is a clause commonly found in honorific inscriptions designating where the inscription is to be displayed (and leaving it open for interpretation). 


\subsection{Rational Rituals ${ }^{191}$}

Memory is thus rooted in both place and ritual. Ritual is a conduit for the cognitive need to comprehend the world through structure and order; it reinforces pathways in the brain and patterns in the mind. ${ }^{192}$ According to McCauley and Lawson, ritual is full of structure and repetition that both strengthen memory and enhance the desire or even compulsion to do things in 'the right way'. ${ }^{193}$ Collective ritual is especially concerned with the accurate transfer of knowledge, more so than about religious content. Performance is critical and so ritual is full of mnemonic devices that provide the framework an accurate rendition of ritual; these memory aides are necessary not just because of the frailty of human memory, but also because it is creative and playful, prone to variations. ${ }^{194}$ The ultimate goal of these mnemonic effects, however, is not so much to produce the perfect ritual as it is to create a continuity of community through a shared focus. ${ }^{195}$ Frequent, habitual repetition is one means to this end, but another is through the power of spectacle, the creation of vivid 'flashbulb memories' that particularly heighten the senses, triggering acute recall. ${ }^{196}$ Memories evoked by this type of ritual are more readily passed down through generations by verbal transmissions, re-enactments, or written accounts in literate societies. Successful public rituals are thus those that make a lasting impression. Form and frequency are both important albeit separate dimensions in the memorability of ritual, but especially the factors of sensory pageantry and emotional arousal are strong triggers for the creation of 'flashbulb

191 Chwe (2001), Rational ritual. Culture, coordination, and common knowledge. I am indebted to Josh Ober, who introduced me to Chwe's concepts and the problem of common knowledge and coordination.

192 McCauley and Lawson (2002), 23-24 and (2007), 222, emphasize the capacity for ritual as already present in pre-school children; cf. Tomasello's findings on the early reception of normative actions and ability of cooperation, Tomasello (2009), 45-46. See Ritual Form theory, developed by McCauley and Lawson (2002) and (2007). Also Tomasello (2009); Hervieu-Léger (2000), esp. 124-127. For an overview of ritual theory, see Bell (1992), but also Connerton (1989), 44-53 on psychoanalytic, sociological and historical perspectives to ritual; also Smith (1987) and Grimes (1999) with regard to ritual theory and place.

193 McCauley and Lawson (2007), 211.

194 McCauley and Lawson (2007), 214. Ritual mnemonics are compared to 'prosthetic devices' that help one access knowledge that one already possesses, much in the way that a pencil can help one work through a math equation that is too complicated to do by memory alone. See also Connerton (1989), 57-58 on ritual language as a mnemonic device.

195 McCauley and Lawson (2007), 219-220: "to increase the probability of a communal sense of continuity in the transmission of cultural materials and to decrease the probability of introducing socially divisive variations"; McCauley and Lawson (2002), 83; also Tambiah (1985).

196 McCauley and Lawson (2002), 56-64; Czachesz (2010) on the accuracy long-term effects. 
memories.'197 The miracle of Zeus at Panamara, while not a ritual in itself, would have created such a 'flashbulb memory' that was relived by later generations through the processions of the god coming down to Stratonikeia, but also through reading the story written on the walls of the temple. ${ }^{198}$ The priests of Hekate at Lagina also hosted spectacles, especially music and games, that kept escalating in scale in the imperial period, no doubt in order to retain their spectacle impact. ${ }^{199}$ These imperial eccentricities are part of a trend towards spectacle that is characteristic of the Hellenistic period, as Angelos Chaniotis has made clear. ${ }^{200}$

The cognitive approach to ritual focuses on form rather than content or symbolism. ${ }^{201}$ For Paul Connerton and especially Michael Suk-Young Chwe, form is content. The ultimate goal of ritual is social cohesion, channeled by the collective memories that ritual creates, as Connerton stresses, or by common knowledge, as Chwe puts forth. ${ }^{202}$ This approach to ritual is a significant departure from the standard set by Emile Durkheim, in which ritual corresponds with underlying social realities, rather than actually producing them. ${ }^{203}$ Focusing on form alone exposes the communicative mechanisms of ritual and illumines its capacity to create joint attention by generating common knowledge - the prerequisite to the sense of 'we'-ness that lies at the base of a cooperative community. ${ }^{204}$

Public ceremony, then, is all about capturing the attention of the participants, to spark a shared experience by creating a common focus, whatever this focus may actually have been. 'Rational rituals', as the game theorist Michael Suk-Young Chwe calls them, thus generate common knowledge, the root of collective identity. ${ }^{205}$ Common knowledge is any knowledge that is not only mutually shared, but that is especially known to be mutually shared; this

197 McCauley and Lawson (2002), 89-178 and more concisely in McCauley and Lawson (2007), 236-246.

198 The event is related in I.Stratonikeia 10; see below, Chapter 6.

199 Peer rivalry would have been a factor, see Chapter 5 .

200 Chaniotis (1997), (2010), and (2013).

201 Summarized in Connerton (1989), 44-53.

202 Connerton (1989), 47-71; Chwe (2001), discussed below.

203 Durkheim (1912); also Rappoport (1979), on ritual as reproducing social classes. It goes beyond the scope of this work to discuss what many other have done so succinctly, esp. Bell (1992), 171-223.

204 Tomasello (2009), 69-77; also Collins (2004), discussed further in Williamson (in press-b).

205 Chwe (2001), 6: "To understand public rituals, one should understand how they generate the common knowledge that the logic of rationality requires. To understand how rational individuals solve coordination problems, one should understand public rituals." On group identity, Chwe (2001), 91-94. 
forms the basis for any kind of joint action or collaborative effort. ${ }^{206}$ Shared experiences and opinions enable a group to define itself, but how is cohesiveness created in the first place, and how can everyone's participation in joint action be guaranteed? This is the classic problem of coordination in rational choice theory, and Chwe believes that public rituals are the key: by capturing everyone's attention simultaneously, a shared experience is immediately created - everyone knows that what they experience is common to all. ${ }^{207}$ The significance of public rituals then lies not so much in their meaning, verbal content, cosmological symbolism, or even historical context, ${ }^{208}$ even though these may emphatically declare shared belief and intention. The significance rather lies in the way in which they are delivered. ${ }^{209}$ Public rituals are media; like advertising campaigns, they make sure that everyone is not only aware of the product, but is also talking about it with each other. ${ }^{210}$

Visuality is therefore crucial. In order to maximize their coverage, stationary public rituals are therefore best performed in 'inward-facing circles' where everyone can not only observe the main event, but can also observe each other's reactions. King Arthur's Round Table, pueblo kivas, modern parliamentary chambers and town halls are all built on this concept, called 'the magic circle' by medievalist Johan Huizinga - worlds in themselves where different rules apply. ${ }^{211}$ The bouleuterion (council house), the stadion, and especially the theater and odeion (recital hall) are excellent examples of performative spaces in the round in the ancient Greek world, set apart in urban topography. ${ }^{212}$ These ritual spaces are shaped by embodied ritual action, since this is always 'forsome-goal' or 'for-someone' and therefore demands an audience, as David

206 The mutual experience of "I know that you know that I know that you know, etc." is gained primarily through eye-contact, also known as 'recursive mind-reading': Tomasello (2009), 72 : “... recursive mind reading ... is the cognitive underpinning of all forms of common conceptual ground."

207 Chwe (2001), 11-13, 74-94; the problem of coordination is further described in Chwe (200o). Turchin gives a comprehensive overview of this aspect with regard to rational choice theory and theories on cooperation, in Turchin (2006b), 107-137. Ober addresses this problem with regard to the rising democracy in Athens in Ober (2008), 168-210.

208 Chwe (2001), 19 cites Lynn Hunt on the French Revolution: "... political symbols and rituals were not metaphors of power; they were the means and ends of power itself," Hunt (1984), 5 .

209 In this regard Chwe differs from Weingast (1995), 450-455, who considers a shared belief system as the solution to the problem of coordination.

210 Chwe (2001), 21, 37-49.

211 Huizinga (1949), discussed further in Guano (2013). See also Williamson (in press-c).

212 Chwe (2001), 25-33. Greek theaters were used for several other civic events besides theaters, Chaniotis (2007) and van der Vliet (2011). 
Parkin argues. ${ }^{213}$ Joannis Mylonopoulos further discusses ways that spectatorship is built into sacred space, to allow the audience to observe ritual mimetic actions such as sacrifices or mystery rites, since viewing itself is part of the ritual. ${ }^{214}$ Sanctuaries were designed to accommodate these 'ritual mimetic actions' and should be studied from the angle of the observer. Some had theaters of their own, but more often they were equipped with stairways, tiers or steps that served as a tribune, or theatron, as with the sanctuary of Hekate at Lagina. ${ }^{215}$ Chwe goes one step further, however, in emphasizing that the participants should not only be able to see the ritual, but also to make eye-contact with each other. It is with these factors in mind that I designate the nodes (in Lynch's spatial syntax) of ritual activity at sanctuaries as concentric spaces, emphasizing the centripetal focus, the potential for mass spectatorship, and the capacity for the mutual gaze. Architectural defined spaces with a clear central focus serve this function, whether they are actually round or not.

Besides rituals in a centripetal space, processions provide another excellent avenue of common knowledge as the focus of the spectacle is moved around to reach the widest possible audience. ${ }^{216}$ Whereas Clifford Geertz, like de Polignac discussed above, had argued that processions are primarily about territorial domination, ${ }^{217}$ Chwe contends instead that their ultimate goal is publicity, ensuring maximum coverage as an extension of the ritual dispersion

213 Parkin (1992), 17; in his view of ritual as "formulaic spatiality" he argues that ritual revolves around physical performative actions, rather than words spoken (or sung?); also Tambiah (1985); Bell (1992), and later Hull (2014) on the social value of rituals in "persistent places" in small-scale societies.

214 Mylonopoulos (2006). On p. 92 n. 95 he quotes Durand (1989), 119: "To celebrate a rite is to do something ... the spatial distribution of actors and actions, the layout of the space itself, the unfolding and organization of the series of movements, the atmosphere and geography of the rite - all are critical." Mylonopoulos' main examples include the Amphiaraion of Oropos, the Kabeirion on Samothrake, the Demeter sanctuaries at Corinth and Pergamon, and Brauron. On the phenomena of cultic theater, Nielsen (2002), 138, and 266, ranking Lagina among the Anatolian sanctuaries of goddesses affiliated Kybele, possessing a theatron.

215 See also Hollinshead (2015) on monumental staircases; on ritual drama, Nielsen (2002).

216 Chwe (2001), 20-22.

217 Geertz (1983), 132: "Royal progresses ... locate the society's center and affirm its connection with transcendent things by stamping a territory with ritual signs of dominance ... When kings journey around the countryside ... they mark it, like some wolf or tiger spreading his scent through the territory, as almost physically part of them," cited in Chwe (2001), $20-21$. Chwe argues that this lone wolf analogy ignores the point of publicity and attention. Processions as power displays were discussed above in connection with 'extra-urban' sanctuaries, de Polignac (1995) etc.; see also Seed (1995) on processions of domination by Europeans in the New World. 
of common knowledge. ${ }^{218}$ For remote sanctuaries in antiquity, however, various factors may have been at work simultaneously. The processions known from Lagina and Panamara drew the entire diverse and socially stratified community across the landscape, creating a sense of community while connecting areas of significance as they progressed outwards towards the sanctuary and then back towards town. Chaniotis in particular has shown how such processions, apart from their element of spectacle, embodied the ideal civic and social order, with everyone taking their place. ${ }^{219}$ This is an important departure from Turner, who endorses the element of communal bonding during non-urban processions and festivals, yet stresses their primary aim of creating an alternative 'anti-structure' community, distinct from the social order of the urban center. ${ }^{220}$ Turner is, however, right to highlight the agency of geography. Processions were excellent community builders with their vehicles of common knowledge, as Chwe argues, but landscape itself would also have been integral to the experience, a common focus in its own right as it literally passed before the eyes, ears, noses, hands, and feet of the community. This is why I designate sacred roads as kinetic linear space, incorporating movement and direction, as discussed above. Woven into the topography, sacred roads were also part of social and urban space: processions turned travelers into performers of landscape. ${ }^{221}$ Processions to country sanctuaries were not only essential to producing a sense of community, but also a sense of common territory.

Processional routes and inward-facing circles are highly charged spaces. Activating them through rituals can have powerful consequences. Arenas and stadia are notorious scenes of riots, e.g. Pompeii in AD 59, or the Nika revolt, while Chaniotis has also argued that the emotional force unleashed by festivals did not always have the intended effect. ${ }^{222}$ Rituals are excellent coordinating mechanisms, but also highly volatile if not carefully controlled. Thinking of

218 Chwe (2001), 20-21: "Progresses are mainly a technical means of increasing the total audience, because only so many people can stand in one place; common knowledge is extended because each onlooker knows that others in the path of the progress have seen or will see the same thing. That the monarch moves is hence not crucial; mass pilgrimages or receiving lines, in which the audience moves instead, form common knowledge also."

219 Chaniotis (1995), 158-16o; Chaniotis (2006) and (2013). See also Graf (1996); Chankowski (2005); Mylonopoulos (2006), 104-107; Viviers (2010); Connelly (2011); Stavrianopoulou (2015), also Huet (2015), although focused on the Roman world.

220 Turner (1973) and (1974a), discussed above in the introduction.

221 On landscape as performance: Dwyer and Alderman (2008); Pearson (2015); also Donaldson (2006) on 'performing the region', discussed below.

222 Chaniotis (2006), on how they were not always as beautiful as intended, with the range of emotions at these intensive events, and the need for rules and mob control. 
urban festivals at country sanctuaries in this way allows us to interpret their role in creating social cohesion, like any other sanctuary. Unlike other urban festivals, however, it also highlights the function of the procession and hence landscape and its role in defining territory and a communal sense of belonging. Viewing these phenomena through the lens of 'rational rituals', rather than simply territorial domination or social hierarchies, makes us look for the object of common focus, whatever this may have been - landscape, object, ritual. Furthermore, it compels us to understand them in their social and spatial contexts, linear or concentric, as part of a performance that generated common knowledge, and thus a sense of unity that would have been so vital to rising poleis.

\subsection{Network Models}

Besides highlighting their capacity to foster internal social cohesion, the lens of 'rational rituals' also allows us to consider the potential of country sanctuaries as nodes in wider networks. This can follow two theoretical directions, both drawn from the sociological sciences. The first is to return to the aspect of memory with a focus on the assemblage of material culture at sanctuaries and its value in creating a coherency of associative relationships for the community involved at the sanctuary - this is aligned with Actor-Network Theory. A second direction is to follow a more general application of network theory to understand the function of the sanctuary itself as a central node in a web of cult relationships, and how this may have been exploited by the polis to establish its own position in the region.

Actor-Network Theory (ANT) was developed by Bruno Latour as a reaction against the rigid ontological hierarchy that underlies traditional theoretical frameworks within classical sociology. ${ }^{223}$ With ANT, he proposes instead a very flat model of objects without distinction, so that humans and objects possess equal potential to bring about change, whether they are 'macro actors', such as institutions, or 'micro actors', such as individuals or things. ${ }^{224}$ Essential to this is the connectedness of things to the past and their ability to trigger memories, all of this occurring within a highly diffuse and constantly changing assemblage of associations, as in a network. ${ }^{225}$ Latour is against setting

223 Discussed in Latour (2005), 13-15. Latour's groundwork is set out in Latour (1987), Science in action. How to follow scientists and engineers through society.

224 An actor is, simply put, anything that causes change. "... if an actor makes no difference, it's not an actor," Latour (2005), 130. See also Alcock (2002), 28-30; Rowlands (1993), 44 stresses the role of objects as mediators of past and present.

225 "Network is a concept, not a thing out there. It is a tool to help describe something, not what is being described," Latour (2005), 131. 
out a theoretical framework in advance, as I am now doing, but argues instead that one should 'follow the actors themselves', tracing lines of associations to see where they lead. ${ }^{226}$ The principal merit of ANT for this present research is its presumption that things, such as landscape, architecture, or imagery, influence human behavior and create a web of connections as they do so. ${ }^{227}$ This may be applied, for example, to the ritual spaces that I discuss further in this research that were engineered by humans, yet in turn served to influence the way humans perceive themselves and each other, determining even the nature of the ritual performances that took place there. The spatial settings were often defined by architecture, and the style chosen would have brought with it associations that informed the observer about the type of space that he or she was in, e.g. the half-smooth stoa columns at Lagina were very agorareminiscent, signaling urban space. This person may in turn have left graffiti on the architecture, as they did on the steps of Hekate's temple at Lagina and in the propylon, that again modified the general associations emanating from these structures, and influenced subsequent visitors, and so forth. ${ }^{228}$ This short sketch is but one example. Of the case studies addressed in this current study, ANT has proven most fruitful with regard to Labraunda, especially following Guggenheim's adaptation of ANT for architecture and memory. ${ }^{229}$ Whereas Latour focuses on the mutability of things through their mobility, Guggenheim instead focuses on the mobility of humans around and through immobile but nonetheless mutable architecture. Moreover, architecture can possess a longer time-span that reinforces its ability to invoke memories of the distant past. This has helped discern the web of associations at the fourth century complex at Labraunda, invoking its Hekatomnid past, that was employed by Hellenistic Mylasa to legitimate its position in the region in the third century вс. ${ }^{230}$ The initial results of this analysis using ANT show how the evocative power of objects could also be employed to create or induce a focused ritual experience. In the context of this research ANT especially helps understand how certain artifacts were given a role in creating a mindset that made the bond between a sanctuary and the nearby polis seem logical and natural. Actor-Network Theory has valuable potential as a tool for elucidating such webs of associations and

\footnotetext{
226 Latour (2005), 12.

227 Guggenheim (2009), 41.

228 The sanctuary of Hekate at Lagina is discussed in Chapter 5 .

229 Guggenheim (2009); see also Alcock (2002), 28-32, on the role of monuments and memory.

230 Discussed at the end of Chapter 3.
} 
it would be worthwhile to further explore its potential in combination with studies of landscape or spatial memory. ${ }^{231}$

Rather than the plethora of associations that ANT addresses, most applications of network theory tend to focus on relationships between things in kind. As discussed above, Horden and Purcell presented a sweeping view of the Mediterranean as a complex network of micro-regions, tightly linked through the 'productive environment' and the 'cult network'.232 For the Greek world, the model of peer polity interaction developed by Colin Renfrew and John Cherry to interpret the developments of the Early Bronze and Iron Ages marks a step in this direction. ${ }^{233}$ Debord had already suggested that religious festivals were hubs in trade networks in Asia Minor. ${ }^{234}$ In fact, his work spans two distinctive paradigms: his focus on the urban-rural axis is rooted in the underlying core-periphery model, whereas his attention to geography, roads, and these trade networks also gives weight to connectivity and interaction between communities and states.

Core-periphery and network models represent two different ways of looking at such distant urban sanctuaries - either as beacons of the polis, marking its frontiers, or as hubs of interaction in a wider network of cult. ${ }^{235}$ Network models, however, tend to be applied as counterpoint to the strong hierarchy of space and society inherent to Central Place Theory and implied in the coreperiphery model. ${ }^{236}$ Rather than a series of uni-directional relationships, networks present a much more dynamic and dispersed image, both socially and geographically - one that relies on multiple interconnections to function..$^{237}$ Network theory has earned its place as a paradigm in studying the ancient world, due in part to Horden and Purcell's monumental study, but also to early pioneers such as John Bintliff, who in 1977 used networks to explain the rise of Mycenae as regional super-center, and Madeleine Jost, who in 1994 discussed the network of sanctuaries across rural Arkadia. ${ }^{238}$ More recently, Irad Malkin explored network approaches as an alternative lens for interpreting Greek

231 Spatial uses of ANT: Madden (2010); Allen (2011); also van Oyen (2016).

232 Horden and Purcell (2000), 403-46o.

233 Renfrew and Cherry (1986).

234 Debord (1982), 24-25, discussed above.

235 As mentioned above, de Polignac also examines the mediatory role of such sanctuaries in de Polignac (1994). Also, not every sanctuary in every border area should be interpreted as having had the same function.

236 Christaller (1933); Hopkins and Wallerstein (1982), discussed above in Chapter 2.

237 See Meijers (2007), for an excellent analogy regarding hospital catchment areas, assessing the paradigm shift from a centristic towards distributed approach in the Netherlands.

238 Bintliff (1977b), 88-92; Jost (1994). 
colonization. ${ }^{239}$ Christy Constantakopoulou has effectively applied network theory in her analysis of Delos and the Cyclades, ${ }^{240}$ while Tom Brughmans, Anna Collar, and Fiona Coward have made major methodological advances in applying this in archaeological and historical contexts. ${ }^{241}$ The most popular form of network analysis is Social Network Analysis (SNA), which addresses the flow of information through individual contacts, focusing on people as nodes and their relations as ties (or edges). ${ }^{242}$ Not every dataset can support the full range of such intensive quantitative analyses, yet when shifting the focus to the dynamics of relationships and connections, this approach can generate new lines of inquiry. ${ }^{243}$ Network analysis could address, for example, whether sanctuaries functioned as specialist nodes in a wider cult network (e.g. oracles, healing cults, sanctuaries belonging to associations and federations), or how their festivals were levied by poleis to engage with their peers and other powers. ${ }^{244}$ Many avenues of research are opening up, but for the present purposes the theory will be used to investigate the role of sanctuaries as mediators in inter-urban networks based on ties of cult.

The vitality of a cult network might on the one hand lend support to the idea of a continuation of the (semi-)autonomy of sanctuaries. On the other hand, close scrutiny is called for regarding the agents of network. John Ma views this against the wider background of interacting poleis, which he describes in terms of peer polity interaction. ${ }^{245}$ Borrowing the term from Renfrew and Cherry, who used it to explain change in Bronze Age Greece, Ma inverts the model to explain stability and continuity in the otherwise highly turbulent Hellenistic

239 Malkin (2005) and (2011). See Malkin et al. (2007) and the contributions in Mediterranean Historical Review 22.

240 Constantakopoulou (2007) and (2017).

241 Brughmans (2013); Collar (2013); Brughmans et al. (2015); Brughmans et al. (2016) and the Connected Past consortium, connectedpast.net.

242 A good explanation of SNA is found in Collar (2007); Brughmans (2010). The importance of random or 'weak' ties versus intensive or 'strong ties' in creating a 'small world' is addressed in the seminal article by Granovetter (1973) and (1983). The 'Small World' model, based on the widespread phenomenon of mutual acquaintances, was further developed by Watts and Strogatz (1998). See also Gould (1993); Wasserman and Faust (1994); Chwe (2000); Scott and Carrington (2011).

243 The possibilities and limitations for the archaeological application of SNA are discussed among others in Brughmans (2010) and (2012).

244 Van Nijf and Williamson (2016) and the website connectedcontests.org and the research project Connecting the Greeks. Multi-scalar festival networks in the Hellenistic world, at the University of Groningen (2019-2023), sponsored by the Netherlands Organisation for Scientific Research (NWO) and conducted at the University of Groningen, see connectingthegreeks.com.

$245 \mathrm{Ma}$ (2003); Renfrew and Cherry (1986). 
period. In a lucid exposé, he discusses the central importance of connectivity and mutual recognition as a joint venture between poleis that created strong horizontal bonds counterbalancing those between rulers and cities. ${ }^{246} \mathrm{Ma}$ identifies four prime mediators in these inter-polis relationships:247 1) syngeneia, or kinship, used to establish a link with other poleis based on some ancient or mythical shared ancestry, often involving moral obligations; ${ }^{248}$ 2) asylia, a declared inviolability of a sanctuary that required recognition from the wider Greek world; ${ }^{249}$ 3) theoroi, embassies from poleis who traveled to different sacred festivals, often announcing festivals in their own cities; ${ }^{250}$ and 4) arbitrators, or foreign (neutral) judges called upon to settle disputes between poleis. ${ }^{251}$ Ma shows how these four vehicles of connectivity with the wider world not only reflect the mental maps of the various poleis, but actually served to create them. ${ }^{252}$ This study will examine all but the last of these criteria. Asylia is particularly interesting as a term of brokerage between cities, since the concept is commonly understood by scholars as an expression

$246 \mathrm{Ma} \mathrm{(2003),30:} \mathrm{"Peer} \mathrm{polity} \mathrm{interaction} \mathrm{was} \mathrm{a} \mathrm{collective} \mathrm{work} \mathrm{...} \mathrm{A} \mathrm{mesh} \mathrm{of} \mathrm{strong} \mathrm{horizon-}$ tal connections of collaboration, assertion and recognition was an eminently desirable thing in a world of powerful vertical pressures tending towards integration and subordination. The existence of a network of dialogue between cities meant that the relation between any local community and a ruler was never exclusive, because the local community also participated in a world of polis relations ... To a considerable extent, the protocols of peer polity interaction shaped the parameters of superpower behavior."

247 Listed in Ma (2003), 14 and discussed throughout the article. His focus on broad network contacts is probably why he does not mention sympoliteia, or civic mergers, although these typically resulted in the 'twin stelai' phenomenon - different cities which share the same decrees in their public (usually sacred) spaces. This phenomenon is addressed in the doctoral research projects of Sjoukje Kamphorst at the University of Groningen and Marie Drauschke at the University of Münster.

248 On syngeneia in general: Noack (1951); Bresson and Debord (1985); Curty (1995); Will (1995); Jones (1999); Lücke (2000); and Erskine (2003). The letters written by the priest of Panamara in I.Stratonikeia 22-39a are examples of this kind of syngeneia, discussed in Chapter 6; the syngeneiai at the sanctuary of Sinuri were more internalized, see Chapter 4.

249 On asylia: Gluskina (1977); Mastrocinque (1984); Belloni (1984a); and especially Rigsby (1996); on territorial asylia, now Knäpper (2018).

250 On the role of theoroi, and their hosts, the theorodokoi, as linchpins in inter-poleis networks: Perlman (2000); Kowalzig (2007a); Rutherford (2007), addressing theoric networks; Rutherford (2013).

251 Kantor (2016) addresses this at Mylasa in the imperial period. Examples in the Hellenistic period include Iasos, Blümel (2007), 42-46 (translated in Blümel et al. (2014) no. 50), with judges from Knidos, and Iasos, with judges from Priene, Crowther (1995) and Crowther (1993). This is further addressed in the doctoral research of Sjoukje Kamphorst at the University of Groningen.

$25^{2}$ Ma (2003), 19-22. 
of the hierarchical bond between ruler and city. ${ }^{253}$ Ma acknowledges that his interpretation intentionally bypasses this vertical dimension in focusing on the horizontal operations of the inter-polis network. ${ }^{254}$ Yet this raises two problems: one is that several new cities were in fact founded by rulers (hence Debord's bias towards urbanism), ${ }^{255}$ and the other is the critical role of the new 'local panhellenic' festivals as major generators of urban interaction, which Ma acknowledges but omits from his analysis as he attributes their origin to rulers. ${ }^{256}$ Rulers may well have stimulated these festivals in part, but it was clearly taken over by cities making it even more worthwhile to investigate their role in the dynamics of peer-to-peer urban networks.

Even more important in understanding how urban networks worked is the role of sanctuaries as hubs as principal channels of communication between communities. ${ }^{257}$ In fact, Ma ends his article with allusions to the annual rituals that were part of the network-forming processes, the words spoken, the joint sacrifices, the tokens exchanged. ${ }^{258}$ Vehicles of common knowledge, these may certainly be interpreted as rational rituals, even lieux de mémoire. This once again demonstrates the role of ritual in creating community, but also helps explain the rise in inter-urban 'panhellenic' festivals in the Hellenistic period. ${ }^{259}$ Cities generally presented themselves to each other through their gods and so it makes sense that the sanctuary that helped pull communities inwards to become a polis would be the same shrine that that polis would

253 E.g. Boffo (1985), discussed above in Chapter 2. Ma (1999), 157 briefly discusses administrative aspects of asylia under Antiochos III in the context of internal status and external diplomacy, also p. 172-173 and his discussion of the Teian decrees of asylia, p. 160-165.

254 Ma (2003), 27: “... the picture I have given for peer polity interaction in the Hellenistic world has deliberately omitted the supra-polis powers, Hellenistic kings and regional leagues, and finally the intervention of Rome. These powers impinge only weakly in the account of institutions and symbolic discourse; yet their preponderance was obvious."

255 See Cohen (1995) and Mileta (2009b) on royal foundations of cities; Ma (2003), 38.

$256 \mathrm{Ma}(2003), 27$, discussing the Ptolemaia in Alexandria, founded by Ptolemy II, as "the first for which the Greek communities were formally requested to grant acceptance as 'panHellenic'..." Here he follows Robert (1984), 35-45; ruler involvement is further discussed by Cohen (1995); Aperghis (2005); Mileta (2009b), 82-87, and now Strootman (2014). But see Parker (2004) who underscores the growth in 'panhellenic' festivals as a civic initiative; also Chaniotis (1995) and Wiemer (2009), 117. On the civic dimensions of athletic contests: van Nijf (1999) and (2012); also van Nijf and Williamson (2015) and van Nijf and Williamson (2016) on festival networks.

257 Several instances of connection in Ma (2003) concern sanctuaries: e.g. three of his four basic terms almost always refer to sanctuaries (p. 14); the "traveling decrees" were typically set up in sanctuaries (p. 19-22); individuals were often honored by foreign cities in the sanctuaries of their own towns (p. 17-18).

258 Ma (2003), 39.

259 Parker (2004). 
use to interact with the outer world of cities - as is the case with Lagina and Stratonikeia, where many layers of intra- and inter-urban identity melded at the shrine - this is further discussed in Chapter 5 .

The level of data collection required for sophisticated network analysis exceeds the scope of this current investigation, yet even a metaphorical application of network theory will demonstrate that sanctuaries such as Labraunda and Panamara were also active hubs in a wider web of contacts that extended beyond the territory of their respective city. At the same time, it will show how the shadows of city and sanctuary began to emerge and fuse together. The mediatory formulas of syngeneia and asylia are, among others, good barometers for gauging the exploitation of a sanctuary by a polis as it defined its place in the regional political landscape.

\section{$2.4 \quad$ Regional Identity}

With their emphasis on a centralizing government and its institutions, young or expanding poleis will have had many of the same needs as any developing state: the need to create a common and shared identity, the need for a joint goal, and hence joint attention, but also the need to be recognized externally. These factors were discussed above in connection with rational rituals and network dynamics. Yet particularly the geographical distance between the urban centers and the sanctuaries in which they invested their identity, combined with the territorial concerns that many poleis had, make it worthwhile to consider these factors through the lens of regional identity building. 'Region' is an ambivalent term and can mean many things in many contexts and scales. In antiquity, it is used to designate larger areas encompassing multiple poleis with a common cultural heritage. Karia, for example, has been examined from this perspective by Gary Reger. ${ }^{260}$ In this study, however, I use the concept as an analogy to understand key processes in the development of a polis, how it establishes its administrative center and consolidates its greater territory, including the sanctuaries and dispersed communities.

Drawn from the social sciences, modern studies on regional identity usually focus on agency in creating a central identity, but with the advantage of being able to conduct interviews with the actors. Rooted in data and grounded theory, this approach dismisses any larger theoretical framework, like ANT or SNA. ${ }^{261}$ Archaeological and historical data, however, rarely allow for this level

26o Reger (2007), (2011), and (2013). Federations and leagues also give ancient perspectives on region.

261 'All is data' is one of the basic tenets of grounded theory, developed by Glaser and Strauss (1967). In this approach, the field notes taken from interviews are turned into 'open code', 
of granularity, but they can show the effects of decisions taken by individuals, even if we do not know who they were. The data from the case studies allow for the discernment of larger patterns and in fact show striking parallels with the stages of development in constructing a modern regional identity as identified by Anssi Paasi, whose work I draw on in this section. ${ }^{262}$ His studies incorporate the roles of boundaries, symbols, and identity into a framework of region that revolves around the process of institutionalization, resonating with Ma's focus on institutions as the common ground of urban interaction. Paasi identifies four critical stages in the process of building a region: territorial shaping; symbolic shaping; institutionalism; and the establishment of the region through external recognition. ${ }^{263}$ Each stage has a bearing on the present research.

The very base of a region, in Paasi's view, is territorial shaping. ${ }^{264}$ According to him, attachment to territory relies on "four experiential dimensions." These include: the social, with those who inhabit it; the political, concerning expansion; the cultural, with collective memories; and the emotional, which amplifies identity. ${ }^{265}$ Boundaries are instruments of territorial identity not just as border, but because they give territory a cartographical shape that can acquire an iconic function, as it comes to symbolize the space occupied by a region. A caveat with ancient poleis is that we are seldom able to identify their boundaries, although it is probably safe to assume that most of the citizens would have had at least some idea of where they were or were not. ${ }^{266}$ A separate issue is that in antiquity people's 'mental maps' were not informed by the bird's eye view, and so we should instead think of their idea of territory in terms of the 'cognitive collages' of hodological perspectives, or 'street-view' of the landscape. This is the point where visual regionalization can overlap with the spatial definition of urban territory, which in antiquity extends beyond the walled spaces. Natural features such as mountains, rivers, trees, and of course sanctuaries would have been landmarks that helped give this territory a shape in the minds of the community. Linear rituals, such as processions that by repetition created an intimate familiarity with the landscape, were equally critical

in which everything is presumed to have meaning - these are then cross-referenced, i.e. turned into 'axial codes' and eventually from this the 'theoretical code' is ultimately distilled; see also Corbin and Strauss (2008).

262 Paasi (2009).

263 Paasi (2009), 133-137, on the development in the nineteenth and twentieth centuries of the concept and its later resurgence.

264 Paasi (2009), 123-124, argues that, despite internet and globalization, "... the contemporary world is still a complex constellation of more or less bounded spaces that exist at various spatial scales. These spaces are 'regions' or 'territories'."

265 Paasi (2009), 124.

266 E.g. testified by boundary disputes, Ager (1996). 
as they marked the natural landmarks but also the villages, tombs, and shrines en route that foregrounded these key places. These rituals all enabled the community to 'perform the region', as they tied territory and community together by collectively crossing the countryside now designated as belonging to them as a city. ${ }^{267}$ This is a very different approach to territory from that discussed at the beginning of this chapter, in which frontier sanctuaries and ritual processions primarily symbolize territorial domination. Much more in line with this approach is the concept of social spatialization, developed by Rob Shields, through which the territory of a region is built into the collective imagination of the community as well as in its institutions. ${ }^{268}$ This is especially clear in the case studies of this present research as well as their festivals, which played a central role in the symbolic shaping of the region of the polis.

Symbolic shaping is the second stage in the formation of regional identity and can take many forms besides the shape of the territory on the map. One is the landscape itself, parts of which can be stereotyped and idealized as inherently characteristic of the region, such as a mountain, forests, or a panoramic view. ${ }^{269}$ Modern media helps generate imagery of the landscape but in antiquity local mythologies and legends should also be considered in this light. An example is the frieze with personifications of local landscape features on Hekate's temple at Lagina, or the expansive view of the Mylasan plain and southwest Karia, 'framed' through the architecture at Labraunda. ${ }^{270}$ Names are also critical, not just the persistent use of a regional name, but also re-naming places, or in this case renaming deities. ${ }^{271}$ Paasi further mentions the power

267 Donaldson (2006), also 'performing the landscape', Dwyer and Alderman (2008); Pearson (2015). This of course involved a high degree of ritual dynamics, studied in detail for festivals and processions especially by Angelos Chaniotis, e.g. Chaniotis (2013), discussed above. This is very different from the kind of 'regional cult' discussed in Werbner (1977) where, following Turner, sacred and political topographies are separate entities.

268 Shields (1991), 31: he uses the term to encompass the physical interventions in the landscape, such as the built environment, within the social imaginary.

269 Meinig (1979), 164: "Every mature nation has its symbolic landscapes. They are part of the iconography of nationhood, part of the shared set of ideas and memories and feelings which bind a people together." Meinig further discusses here landscape as embodying American ideals and values, and how the media serves to propagate this image. Of course, stereotyping a landscape in this fashion already implies a super-regional consciousness, by promoting what is 'typical' for the region in question, and therefore 'atypical' of the others.

270 Labraunda is discussed below in Chapter 3; on the 'south' frieze of the temple at Lagina, see Chapter 5 .

271 Stratonikeia changed the epithet of Zeus Karios to Zeus Panamaros, and gave Hekate at Lagina a new epithet, of Soteira. At the same time, Stratonikeians increasingly included the demotic in their personal names, reflecting the older villages which had 
of allegory, or legends, as a symbolic depiction of a region, usually in a struggle over territorial space; this perfectly fits the Stratonikeian accounts of the epiphanies of Hekate and particularly Zeus in historical crises as saving their city, operating as a charter myth. ${ }^{272}$ Regions also promote themselves through their icons, such as flags, emblems, or a coat of arms; principal deities and their attributes, such as the double-axe of Zeus Labraundos, serve this same function, showing how their images were used to symbolize the polis especially on its coinage. ${ }^{273}$ Finally, festivals celebrating the region play a strong role in creating its symbolic identity; such public ceremonies work as rational rituals, combining community, territory, and institutions in grand spectacles that fix the public focus on the region and its composition, engraining this into the collective memory. ${ }^{274}$ The symbolic shaping of civic territory in the case studies presented here will be found to take place principally through its cults and sanctuaries. The same can be said of most cities in the ancient world, yet it is particularly noteworthy how rising cities turned to cults that were already 'popular' in the area. The social capital, in Bourdieu's terms, of the ancient gods with their local communities was diverted towards the developing poleis. ${ }^{275}$ Deities such as Zeus Labraundos or Zeus at Panamara, with widely acknowledged cults, were transformed into the principal gods of the poleis in whose territory they now found themselves. Festivals were reorganized and their shrines became new urban spaces, drawing the entire community out to the far corners of civic territory. Their images were fixed on civic coinage, daily reminders of the bond between city and sanctuary. Symbolic shaping is the area which especially shows how critical these older resident gods were to the new or expanding poleis, which took their identity from them but also redefined it in the process, so that the two entities, deity and polis, would mesh and become inseparable.

The third stage in building regional identity is institutionalism. This stage represents the development of both formal and informal institutions and overlaps with the first two stages since it is necessary to produce and maintain the territorial and symbolic shape of a region. Regions are social constructs

been absorbed into the polis; see below Chapters 5 and 6. Finally, personal Karian names appear to have been used in Hellenistic Mylasa to recall the Hekatomnid dynasty that had once ruled from there, see Piras (2010), 226-229 and Aubriet (2013), discussed further below in Chapter 2 .

272 These episodes from the turbulent first century BC are discussed in detail below in Chapter 5 .

273 Meadows (2018) on the increasing bond between cities and a main, protective deity.

274 See Connerton (1989), 41-71; Chwe (2001), discussed above.

275 Bourdieu (1986). 
that Paasi argues to be "complicated constellations of agency, social relations and power" in constant flux, with crucial institutions presiding over culture, media, and administration as they are responsible for the "structures of expectation" that are used to build identity narratives and mobilize collective memory: critical agents are especially the cultural/media elite who are best capable of producing the narratives necessary for regional identity. ${ }^{276}$ For the polis in antiquity this means that a major role in defining regional identity would have been ascribed to the priesthood of the deity who stood symbol for the city. Such priesthoods were generally occupied by the urban elite, as will be discussed in the case studies. Paasi's concept of regional identity allows us to examine priests as the media elite, using their cultural capital (again in Bourdieu's terms), to smoothly re-engineer the festivals of these local sanctuaries to meet the needs of the city. 277 Political contact with the wider world almost always transpired through the main urban cults, and priests helped extend the network of cult through grants of asylia and ties of syngeneia, thus embodying the role of statesmen and public relations officials. But besides these official institutions, unofficial practices such as habits and common ways of doing things are also institutions of region. At Panamara we see, for example, how new ritual practices were eventually inscribed in communal memory, such as the unusual but popular dedication of hair in the imperial period. Priests probably had an active role in the design of many of these rituals and were surely central figures in the 'spatial socialization' of the community, helping imprint the territory onto the collective imagination of the community through ritual. ${ }^{278}$ The absorption of these rituals by the community made them key participants in building the spatial framework of regional identity.

A region, or territorial entity, implies some level of political autonomy. For this to be effective, however, it must also be accepted in the social consciousness of the larger network of regions. ${ }^{279}$ The establishment of the region through external recognition is therefore the final stage in the construction of its identity and relies on the successful integration of the previous three stages of territorial definition, symbolic shaping, and institutionalism. Paasi further observes that the institutionalism of a region usually occurs at the expense of other regional units as they are de-institutionalized, either through integration or dispersion. This is exactly what happened at both Mylasa and Stratonikeia,

276 Paasi (2009), 133 .

277 Bourdieu (1986). This is surely one of the main reasons behind the conflict between the priests of Labraunda, who were operating as independent agents, rather than on behalf of the polis, see Chapter 3 .

278 Shields (1991), 31, mentioned above.

279 Paasi (2009), 136. 
visible in the synoikism that lay at the base of the construction of these poleis, as they absorbed the communities around them into their urban body. ${ }^{280}$ The degree of external acceptance is especially demonstrated when other poleis address the newer overarching polis as peer, rather than the older communities directly, even though some of these had once been poleis in their own right. This is, again, where the role of festivals comes in - the diplomatic missions requesting broad acknowledgment of asylia for their sanctuaries and the declaration of inter-urban bonds of syngeneia (kinship) based on cult, and the theoric missions that were launched, all to establish the position of the rising city in the wider network of cities. These networks, as seen above, were based on the homogeneity of institutional contacts, facilitating communication in terms and in the language that was globally understood.

Discussions on the construction of regional identity tend to revolve around the role of the actors, and in the case studies below we can identify rulers as initiators, since they were typically the ones who triggered the synoikisms as at Mylasa or who established colonies as at Stratonikeia. But as such cities gained autonomy and were free to pursue their own course of action; it would have been the governmental bodies and magistrates, made up of urban elite, who initiated territorial and symbolic shaping, who, along with the people, were the ones 'performing the region'. But this is of course a modern perspective. In antiquity, the ones that mattered most in public opinion were the gods themselves - this is why the perception had to be maintained that the bond between the new urban center and the sanctuaries in the ancient sacred landscapes, now political territory, was the initiative and pleasure of the gods. Divine protection over the rising polis and its territory was one of the most critical factors of success in establishing the 'regional identity' of the ancient city, and incorporating these sanctuaries, and their communities, into civic territory was one of the best ways that this could be accomplished.

\section{$2.5 \quad$ Reflection}

Besides the urban-rural, city-countryside, or core-periphery paradigms, there are a number of alternative avenues of investigating the role of country sanctuaries. The paths investigated in this section principally serve to illumine their capacity to integrate landscape and community, while creating a sense of social cohesion and territory unity, aspects that an expanding polis would need to consolidate its new citizen base and present a unified face to the outer world.

280 See the historical development of these poleis, discussed in first sections of Chapters 3 and 5 , respectively. 
This section has examined how familiar landmarks such as sanctuaries can serve to optically compress distance by being 'foregrounded', making them seem closer than they actually are. This is due in part to the way spatial memory works, more as cognitive 'collages' of views and memories, rather than a 'mental map'. The series of views and experiences gained by ritually traversing sacred space would meld into a larger comprehension of place, and cognitive collages could become visual regions. This internalization of space is crucial towards establishing a sense of territory, even more so than delineating boundaries. Space has a social dimension, and concepts borrowed from spatial syntax help distinguish its impact on the ritual experience: 'concentric space' refers to enclosed nodes, with static yet intensive activity, while 'linear space', refers to paths of movement, e.g. processional routes or sightlines that connect places in the mind's eye. Ritual and space are powerful mnemonic devices: combining them in public contexts, especially through spectacles, can create intense experiences and indelible memories. The effect of public 'rational rituals' as mass media in creating joint attention is amplified by space, whether concentric space, with sacrifices or contests, or in linear space, through processions and shared experiences. The common knowledge produced through such rituals is essential to the symbolic shaping of territorial identity, in Paasi's terms. Sanctuaries were also time travelers, accruing webs of associations built on layers of human memory. Network theory helps unravel these connections while focusing on the ties of cult that connected diverse communities, across both space and time. This capacity, besides location, seems to have been a reason that rising cities turned to older established cults as they forged a new sense of community. At the same time, the cult and its festivals formed an authoritative point of contact between the city and the greater world.

The concept of regional identity pulls several of these aspects together in a system that allows us to examine more closely ways that sanctuaries were conductors of identity for rising cities, both from an internal and external perspective. Critical factors of territorial and symbolic shaping, institutionalism and external recognition may be identified in our cases as cities profiled themselves through cult, and are hence incorporated in the analytical approach.

Against this background of methodological concerns and ways of tackling them, we can now turn our focus to the main question - the matter of interpreting the transformation of country sanctuaries in Hellenistic Asia Minor. This study aims in the first place to unravel the logic behind the increasing 
entanglement between rising poleis and autochthonous sacred centers as they were incorporated as mainstream urban sanctuaries, with their local or regional gods being turned into civic patrons. In the second place, the study aims to provide a viable approach of analyzing the changes at these sanctuaries in all their complexity. The typologies, models, and theories discussed in the previous sections provide a number of barometers that can help measure the dynamics in the city-sanctuary relationship, and a brief review will help outline the prime domains of analysis.

The occurrence of sanctuaries on the periphery of a polis is considered a regular phenomenon in the development of the polis landscape of Greece and Magna Graecia in the Archaic and Classical era. Based primarily on archaeological data, studies in this area have demonstrated the importance of cult location in the political landscape, but tend to dwell on categories defined by the urban center and its territorial borders - hence the labels 'extra-mural', 'extra-urban', or 'frontier'. While useful as heuristic devices, these categories can also easily mask the wonderfully complex and messy human situations that sanctuaries respond to. Studies using these categories in fact often isolate cult places in order to magnify their political relevance, particularly in the case of 'frontier sanctuaries'. The core-periphery paradigm that usually underlies this approach generally neglects the fundamental fluidity of sacred landscapes, with connectivities that shift and often transcend political borders. Sanctuaries and their rituals were located in multiple overlapping networks of action and meaning and should be examined in this light as well as their position within political territory and potential as guardians or gateways of frontiers. Meanwhile, scholars of sanctuaries in Asia Minor in the Hellenistic period have taken a very different approach, one that considers sanctuaries in their wider social and economic as well as political contexts. Their studies produce several key indicators that, when explored in depth, can more precisely inform us as to the roles that sanctuaries fulfilled, either in relation to their local communities or to their poleis. Specifically these indicators include: the location of the shrine with regard to roads, economic zones, and surrounding settlements; the presence of local or sacred villages that may have formed the base of its community and administration; the economic resources of the sanctuary and how they were controlled; the nature of the priesthood and how this was office was fulfilled; the degree of ruler involvement. Based largely on epigraphic data. these studies are primarily concerned with historical developments, social geography, legal administration and economy, and the urban mediatization of sanctuaries an sich. They do not, however, address the larger geography of sanctuaries or their role as transformers of the surrounding 
landscape into civic territory, despite the frequency in Asia Minor of civic sanctuaries located in the countryside (see Introduction, Figure 1.1).

Although these approaches show the various roles that a sanctuary may have had, none of them sufficiently addresses the profound dynamics of change: what happens to a sanctuary as it is absorbed by an expanding polis and targeted as the principal locus of urban cult? Many of the major 'extraurban' sanctuaries in Asia Minor began as pre-urban sanctuaries in a landscape that was already socially articulated; often they were already centers of networks of local or more regional communities - sometimes these were known as syngeneia (kinship groups) or koina (federations). How these older social and religious networks were affected by the rise of a nearby polis still has to be assessed. At the sanctuary itself, the change was usually visual through prominent architecture, put up by the city. The way in which this altered ritual space, both inside the sanctuary but also in the wider landscape, is widely acknowledged but seldom examined, even though this played a major part in realigning the perceptions of cult.

Many of these issues are addressed by theories drawn from other disciplines, as discussed in the previous section. In some cases this involves certain fundamental concepts, such as the cognitive perception of space as Tversky has shown, or spatial syntax and how certain public spaces shape behavioral patterns of movement, particularly through nodes and paths as concentric and linear spaces. In this way landscape, architectural space, and ritual action together triangulate the experience of collective identities. Memory is inextricably linked to this combination, and the cognitive theory of ritual proposed by McCauley and Lawson highlights how highly effective sanctuaries and their festivals were in structuring a collective focus for the communities of the shrine. Chwe's concept of 'rational rituals' further informs ways that festivals and processions generated joint attention and thus common knowledge, providing the basis for social cohesion and cooperation. Network theory helps position sanctuaries both internally (locally) and externally, highlighting them as hubs in a larger interurban network based on cult, through which cities promoted themselves and measured their position against their peers, while forging bonds of friendship and alliances communicated through the use of common conventions and institutions. Institutions are finally the focus of studies in building regional identity, which although taken from modern political-geographical studies, strikingly resonate with processes in antiquity that will appear in the case studies mentioned below.

These theoretical approaches are tools to be used where appropriate for interpreting ways that the rising polis grappled with its internal social cohesion 
and territorial integrity, as well as its external position among its peers. The question is whether a pattern can nonetheless be discerned that might help explain why it was as common in Hellenistic Asia Minor as it was in Archaic Greece for a developing city to have a companion sanctuary in the more distant reaches of its territory, but that this came about through very different historical paths. The multifarious mosaic of cultures and settlement types in Hellenistic Asia Minor already shows that models borrowed from other periods can at best address only part of this situation. The danger lies in a seeming fit when viewing the phenomenon in isolation; for example, all of the case studies in this volume may be argued to be located near the limits of civic territory, but to then proceed to interpret them as 'frontier' sanctuaries will take us in the wrong direction. Rather than force a model on several different case studies, it is more useful to take only a few case studies and examine them from a wide variety of angles in order to come to terms with the relationship between city and sanctuary in all its complexity, and as it developed over time.

In light of the above, three central questions rise to the fore. First, how did the relationship between the sanctuary and the polis develop historically? Second, how relevant is the physical environment to this development? And finally, what changes can be identified as a sanctuary was drawn into the orbit of the polis, and how do these indicate urban involvement? These are the main lines of inquiry that in the past have been addressed separately, but need to be integrated in order to acquire a comprehensive understanding of the role of these sanctuaries. They are further developed below.

\subsection{Historical Development}

With regard to the overall impact at the sanctuary of its incorporation into the polis, it is important to gain an understanding of the antiquity of the cult and its degree of 'autonomy' prior to the involvement of the city, as well as the identity of the communities to which it belonged. The studies by Boffo and Dignas especially underscore the significance of any kind of contact with the ruling forces, independent of the polis to which it later belonged. But it is equally important to understand the development of the polis in light of the actors responsible for change as well as the turning points in history that helped determine the course of evolution in this relationship between city and sanctuary over time.

Questions regarding the historical development will include:

- What was the overall impact of the polis on the sanctuary and its community, i.e. what kinds of vertical relationships were there with rulers before or after, and what kinds of horizontal relationships were there with other communities, i.e. how autonomous was the sanctuary prior to the 
advent of the polis, and how was this affected by its incorporation into the urban realm?

- What were the defining moments in the life of the sanctuary that impacted the polis? How smooth was the transition towards urban cult? Can any key actors be identified in the relationship between sanctuary and city?

- How long did this relationship last, did it undergo any noticeable change over time, and what brought it to an end?

\subsection{Physical Environment}

The second factor pertains to the physical environment and the social landscape. Understanding the physical situation of the sanctuary is crucial to interpreting site choice and possibly the connection with that particular deity, but will also shed insight into the significance of both cult and site to the expanding polis. Natural features, the general landscape, e.g. rocky, fertile, forested, but also altitude and climate are all important aspects that could be peculiar to the deity and relevant to human economic, commercial, or strategic concerns. The social and political geography of the sanctuary is equally important. Proximity to territorial borders with neighboring poleis and (sacred) roads might point to a function as frontier sanctuary, while locations near difficult passages could also point to a mediatory function. The overlap of sacred and urban landscapes should also be considered through the continuum lens, connected by places of meaning such as tombs, shrines, settlements, water, economic zones, etc.. Visibility is another concern: the view of the sanctuary and the view from the sanctuary across the landscape, as well as those in between, together comprise the 'visual region' that was appropriated by the polis along with the cult place itself. The visual prominence of the sanctuary was another way of foregrounding it, making distant places seem much closer and thus compacting the perception of civic territory as a comprehensible and natural entity.

Questions pertaining to the social and physical environment will include:

- How did the physical location of the cult place contribute to the identity and development of the sanctuary? What relevance did this have to the city, e.g. strategically or economically?

- Could the social location of the sanctuary have served to integrate community, cult and territory? Is there evidence for a 'continuum' of activity between city and sanctuary? Was it close to roads, settlements, tombs, economic zones, other cults? Was it close to any borders or other communities that might indicate a role of frontier sanctuary?

- Was there a visual connection between sanctuary and city? Did the sanctuary visually dominate the wider area as a landmark? Did the sanctuary connect any viewsheds of importance to the polis? Can the sanctuary be seen 
to be part of the 'territorial' or 'symbolic' shaping of the polis through its location?

\subsection{Urban Integration}

The third category is the most complex as it comprises the many indicators of urban integration that can inform our view of the tightening relationship between the rising polis and the older sanctuary. The central concern is the detection of transition at a sanctuary as it was incorporated into a nearby polis. The transformation of the shrine could be subtle or overt, but in most cases it would have been multifarious. In order to accommodate these complexities, the many avenues of change will be clustered in four larger domains: monumental and ritual space; ritual performance; legal administration and organization; and urban mediatization.

\subsubsection{Monumental and Ritual Space}

Monumental and ritual space is one of the areas with the most potential to show how the physical relationship between the sanctuary, the landscape, and the community was shaped and spatially integrated into a composite whole. In light of the theoretical avenues discussed above, one may ask how the architecture of the sanctuary worked to 'foreground' the sanctuary, as a landmark, with its surroundings in the mind's eye of the community. Space within the sanctuary was also important to the perception or sense of community, particularly enclosed or 'concentric space', as Chwe's inward-facing circles which facilitate rational rituals. Space then not only reflected ritual performance, it also would have shaped it by giving it direction and focus, whether concentric or linear. Visual linear space may have been used in ritual contexts to direct the view and foreground certain areas in the mental maps, i.e. 'cognitive collages', of the community. Doors, windows, and gateways, but also terraces and the use of stoas, can highlight sightlines, indicating an alignment of ritual space towards natural or social features in the wider landscape. Kinetic linear space took the form of roads which physically and ritually connected places of significance, e.g. settlements, shrines, tombs, and the different economic zones. Processions along sacred roads thus ritually connected such places, creating a 'spatial continuum', in Polinskaya's view. At the same time this contributed to the 'territorial shaping' of the regional identity of the polis, in Paasi's terminology. In both respects, the changing visual perspective en route was critical, with the sanctuary situated in either in a continuing 'visual region' from the polis or in a separate one of its own, e.g. blocked by mountains, but connected by a sacred road. 
Questions that should be asked of the architecture and monumental space will include:

- How, by whom, and for whom was monumental architecture employed at the sanctuary? What kind of impression did it make? Did the polis add or change anything to the architectural composition? Was the sanctuary used by the polis as a landmark?

- How did architecture shape ritual space? Can any large public enclosed areas with a focus, i.e. concentric spaces, be discerned in the architectural layout? Were any sightlines emphasized, i.e. visual linear spaces? How were paths used at the sanctuary, i.e. kinetic linear space?

- Were sacred roads connecting the sanctuary to the polis marked in any special way? What kinds of landscapes or monuments did they pass, and how would this have affected the political community? What kinds of 'visual regions' did they connect, and how were these relevant to the polis, e.g. strategically, or through 'territorial shaping'?

\subsubsection{Ritual Performance}

The second area of urban integration concerns ways that ritual performance was impacted by the transition to state cult. Ritual most expresses the intimate and symbolic bond between the sanctuary and whatever community worshiped there, and as such is a good mirror for understanding this relationship, as far as the data permits. Besides monumental architecture, festivals played a major role in foregrounding the sanctuary and its landscape in the mental maps of the citizens of the polis. Frequency and 'sensory value', or the degree of spectacle as McCauley and Lawson observed, are direct ways of both imprinting collective memories and accessing them individually. The ritual actions of the festivals should then be analyzed where possible for their social value, in order to better understand the ways in which joint attention was created through a shared focus. As such they may be gauged as 'rational rituals', in Chwe's terminology. While public rituals can enhance or even produce a sense of community, it is also important to understand how these rituals, or festivals, were redefined by the polis and which communities they were intended to address (and impress). Besides the climactic sacrifices, the processions, banquets, and contests would also have led to a heightened sense of community. All of this would have strongly contributed to the 'symbolic shaping' of the polis as a region, in Paasi's terms.

Regarding ritual performance, the following questions need to be addressed where possible: 
- How did ritual performance contribute to the bond between city and sanctuary? Were festivals reorganized or were any new festivals added to the ritual calendar, especially panhellenic festivals? How often did they take place and were other venues in urban space besides the sanctuary involved? Can urbanizing rituals be identified, and interpreted as 'institutions', i.e. urban habits that were integral to the identity of the polis?

- Can these ritual performances be understood as 'rational rituals'? Which ritual events were used to create joint attention, a communal focus? Were there spectacles, or 'flashbulb memories'? Can rituals be shown to engage or even manipulate social memory?

- For whom were the communal ritual activities intended? Were they geared towards internal social cohesion or a wider interaction beyond the borders of civic territory? Can the festivals be seen to contribute to the 'symbolic shaping' of the polis?

\subsubsection{Legal Administration and Organization}

The third area of urban integration concerns the degree of legal administration and organization of the sanctuary, focusing on the priesthood and cult personnel, but also the local community at the sanctuary and its economic resources. A significant factor concerning the priesthood is whether the polis introduced a new line as civic magistrates or if an earlier organization was still in effect. Debord and Dignas in particular have proven the importance of understanding how priesthoods were fulfilled, whether they were hereditary, annual or for life, and if they were appointed by the polis. The degree of autonomy and authority priests could have is also critical in understanding their urban connection, and whether this derived from the antiquity of the cult or the regime of the polis. Priesthoods were one of the most visible institutions of the polis, and they could fulfill the role of cultural or media elite in Paasi's model of the construction of regional identity. In this function they may have been critical actors in forging the link between the polis and the distant sanctuary. With sanctuaries that were more involved in the wider region, e.g. through panhellenic festivals, priests may even have served as statesmen or public relations officials. Sanctuaries also typically had a local community, as Debord pointed out; the way in which this community was impacted by the incorporation into the polis also reflects the nature of the relationship between city and sanctuary. It is important to know not only where this community lived, e.g. near the shrine, in town, or elsewhere, but also whether its identity changed under the polis, and whether they were included in the citizen body or seen as a separate entity. A third element of sanctuary administration pertains to the economic resources - especially the sacred lands as is so prevalent 
in the area around Mylasa. Such lands would certainly tie the sanctuary to the chora of the polis, shaping civic territory while filling in parts of Polinskaya's 'spatial continuum' with fields and farms, possessed by the divine and worked by citizens (or sacred slaves as the case may be). Yet other sources of income for the sanctuary, such as markets, or even an emporion function, will have figured in the sacred economy as well.

Questions relating to the legal administration and organization of the sanctuary will include:

- Did the sanctuary have a local community and was this noticeably affected by the polis? Where did they live and what was their status, e.g. were they autonomous or were they considered as citizens? What was their role with regard to the cult?

- What was the economic base of the sanctuary, and how and by whom was this controlled? Were there sacred lands that were linked the cult or shrine to the territory of the city, and who administered these?

- What kind of 'autonomy' did the sanctuary still have under the polis? Who controlled the sanctuary, and how was it administered? What was the nature of the priesthood, e.g. conditions of appointment and frequency? Can the priests be identified as major actors in producing (or resisting) urban identity at the sanctuary? How did they contribute to the urban institutionalism of the shrine?

\subsubsection{Urban Mediatization}

Finally, the ways in which the polis used the cult and sanctuary as a platform for its social and political affairs through mediatization forms the fourth area of urban integration. Mediatization concerns the production of realities through their communication, describing here a crucial path of integrating the deity within the urban realm. ${ }^{281}$ The first factor concerns the audience. Besides the local community, it is important to understand the pre-existing scope or network value of the sanctuary in the wider region and how this was impacted by the advent of the polis. If the sanctuary was a hub in a cultic network, the polis may have capitalized on this in some fashion, or it may have even used it as a fulcrum to extend its own network via the 'institutions' of asylia and syngeneia, as demonstrated by Ma, or by the panhellenic festivals to draw in a wider circle of participants. The polis could exploit such a cult network, using it to establish its own identity through external recognition, the fourth stage in Paasi's model of regional-identity building. The sanctuary would moreover have fostered joint attention; besides the shape of ritual space and the rational

281 Hepp et al. (2015); on religious mediatization, Hjarvard 2008. 
rituals of the festivals, this was achieved through the media, the monuments and decrees set up there that reflected urban institutions and created an urban ritual focus through the cult. The nature of the decrees shows the targeted audience of this urban focus and whether it was aimed internally or externally, i.e. towards the polis itself, through honorific decrees or commemorations of events, or outwards, e.g. through interurban contracts or correspondences, or decrees of proxeny. Either way, these media shaped urban memory and set the sanctuary as one of the prime urban spaces in the chora of the polis. But the cult also extended beyond the confines of the sanctuary and into urban iconography. Paasi describes the importance of emblems in the symbolic shaping of regional identity, and the images of the deities of these distant sanctuaries on coinage created an immediate and mobile association between deity, sanctuary and polis.

Aspects of urban mediatization may be discovered through the following questions:

- What was the scope of the sanctuary and how was this impacted by the polis? Was the sanctuary a hub in a network of communities, did other communities join in the festivals there? Was asylia or syngeneia used to compel other poleis to recognize the sanctuary, its festivals, and indirectly the polis? Who initiated these external ties? Do they reflect the establishment of an urban identity?

- How was urban identity mediatized at the sanctuary? What kinds of decrees were set up, what did they concern and for whom were they intended? What kinds of events were commemorated through monuments and how did this impact social memory? Do they reflect an inward focus (social cohesion) or a more outward perspective (political identity)?

- What kind of symbolic capital did the deity possess beyond the sanctuary? Was his/her image or attributes used as an emblem, e.g. on coinage? How did this develop over time and did it contribute to the 'symbolic shaping' of the polis?

These general areas - historical development, environmental factors, and the many changes in form, ritual, administration, media and representation as a shrine is integrated into the urban sphere - all need to be taken into account in order to understand the processes at work in transforming a country shrine into an urban religious center. Table 2.2 (pp. 88-89) gives an overview of these domains, the questions, and the kinds of data that are assessed in the analyses in the rest of this volume. 
Rather than yet another monolithic model, the point is to develop a methodological approach that integrates the various facets involved in the relationship between a sanctuary and a neighboring polis as it begins to expand, working towards an interpretation of the changes that took place in the process. While theory is used to develop a line of inquiry, the investigation begins with a close reading of the data that subsequently is interpreted via the best match in theory. The framework presented here lists the main indicators of urban integration at country sanctuaries and serves as a basic template in assessing sanctuaries, with those in the rest of this volume as prime case studies. Since the relationship between a city and a sanctuary could take a variety of forms, any of these criteria may indicate a bond; they do not all have to be met for a sanctuary to be considered linked to urban identity. Also, data that might address some of these factors may in some cases simply no longer be available. Nonetheless, this framework is a systematic yet flexible tool for comparative analyses that allows us to move beyond categorical explanations to examine the motivations and mechanisms of change. An evaluation for a wider application of the framework as tool is presented at the end of the volume, following the results of the analyses. In the following chapters, the issues listed here will be addressed in each of the case studies, and the answers will vary. Even these few examples, in very comparable situations, will demonstrate that the relationship between city and sanctuary is highly complex and seldom straightforward.

\subsection{The Case Studies}

Over thirty cities in Asia Minor relied on major country sanctuaries, as shown in the introduction (Table 1.1). Many of these were either new or underwent a strong developmental phase in the Hellenistic period, whether at the external initiative of a ruler, as with colonies or synoikisms, such as Pisidian Antioch, or from an internal movement, as with many of the poleis in Lykia, or a combination of both. Ideally all of these connections should be investigated, but as this study also aims to test the framework it will rigorously applied to only a few case studies. The sanctuaries in question should be relatively close to a border, in order to test their potential conformity to the 'frontier sanctuary' model or whether they were even involved with the borders of the expanding polis. Furthermore, there should be enough evidence to address all or at least most of the indicators shown in the table. The main criteria are the availability and quality of data, as well as type (Table 2.2, right column). The overwhelming availability of inscriptions has been noted above, while the archaeology in many cases is still in progress or has yet to be initiated. Monumental architecture has been recorded for the larger part (with some notable exceptions), 
TABLE 2.2 The framework of analysis

$\begin{array}{lll}\text { Indicator } & \text { Looking for ... } & \text { Data type }\end{array}$

Historical

Historical relationship overview of area prior to polis involvement, literary sources, rise of the polis, development of relationship inscriptions, numismatics with the sanctuary, critical events (turning moments), individual actors

Environment

Physical

natural phenomenon, natural

geographical data, geographical borders, landscape cartography, satellite type, availability of water

Social-geographical proximity to polis, and political location boundaries, also to roads, other shrines and villages, tombs, economic resources

Visibility viewshed of the sanctuary (panoramas?), viewshed of polis, visual dominance over the environment/ city territory, role as visual hinge connecting views images

historical topography geographical data, cartography, satellite images, literary sources geographical data, cartography, satellite images architecture

\section{Urban integration Looking for ... Data type}

\section{Monumental and ritual space}

\begin{tabular}{|c|c|c|}
\hline Monumentality & $\begin{array}{l}\text { visual prominence and representational } \\
\text { status, stylistic associations }\end{array}$ & $\begin{array}{l}\text { architecture, monumental } \\
\text { art inscriptions, spatial } \\
\text { design }\end{array}$ \\
\hline Public space & $\begin{array}{l}\text { concentric space: open spaces in/near } \\
\text { the sanctuary for gatherings (festivals, } \\
\text { banqueting) and monuments, visual and } \\
\text { kinetic linear space: paths, gateways, doors, } \\
\text { sightlines, framed views }\end{array}$ & $\begin{array}{l}\text { architecture, inscriptions, } \\
\text { ceramics (all kinds) }\end{array}$ \\
\hline $\begin{array}{l}\text { Processional } \\
\text { routes }\end{array}$ & $\begin{array}{l}\text { kinetic linear space: connectivity (paved?) } \\
\text { between polis and } \\
\text { sanctuary, topographical features } \\
\text { showing a spatial 'continuum', i.e. } \\
\text { monuments, shrines, settlements, } \\
\text { tombs, but also farms and fields, } \\
\text { landscape types }\end{array}$ & $\begin{array}{l}\text { historical topography, } \\
\text { geographical data, } \\
\text { ancient roads }\end{array}$ \\
\hline
\end{tabular}


TABLE 2.2 The framework of analysis (cont.)

Urban Integration $\quad$ Looking for ... Data type

Ritual performance

Festival rituals

bond with polis, ritual focus and joint

architecture, inscriptions, attention, degree of 'spectacle', frequency,

literary sources, ceramics involvement of the wider community (votives)

Banqueting participants, ritual actions, formal and architecture, inscriptions informal banqueting facilities (stoas), water ceramics (tableware) supply, tableware

Games events, location, facilities, participants, architecture, inscriptions, (panhellenic?) competitions \& involveliterary sources ment of the wider community

Legal administration and organization

Administration and priesthoods

Local community

Economic resources

Civic decrees

Cult iconography in urban contexts

Urban mediatization Scope and network

Cult iconography in
urban contexts

degrees of local autonomy and civic institutionalism, controlling parties over the sanctuary and its resources

local settlement at/near the sanctuary, evidence for community-based administration, status as separate community or citizens of the polis

financial base for sanctuary, festival, and priests, integration in landscape via sacred lands, or emporion-function (trade network?)

multiple communities at sanctuary, relationships of syngeneia (kinship), recognitions of asylia (inviolability), presence of theoroi (delegations), athletic participation, coinage distribution public documents, dedications, decrees, grants of asylia, commemoration of specific events deity as emblem of state, evidence of worship of deity in urban center, beyond the sanctuary inscriptions, literary

sources, numismatics

domestic architecture/ tombs ceramics, inscriptions, literary sources

Inscriptions, literary sources

inscriptions, numismatics

inscriptions, monumental art

numismatics, inscriptions monumental art 
yet pottery by comparison is grossly underrepresented in most publications. Recent advances made in the studies of Hellenistic pottery warrant a thorough (re)examination of the pottery at all of the sites mentioned here. ${ }^{282}$

Despite these lacunas, a number of sanctuaries nonetheless possess enough evidence to substantiate interpretations of their developing relationships with an expanding polis. The resulting image will hopefully be greatly nuanced or revised by future studies and especially future progress in archaeological research.

The case studies for this research were selected for their ability to meet the criteria mentioned above, but also for their suitability for a comparative analysis. This will make patterns more evident and reduce the attribution of differences and similarities to local custom. Therefore, rather than drawing a sample across Asia Minor, this study focuses on the exceptionally well documented sanctuaries belonging to two cities in Karia, Mylasa and Stratonikeia (Figure 2.1). Each of these cities has not one but two major sanctuaries in its hinterland that underwent a large-scale transformation in the Hellenistic era. This provides a unique opportunity to examine the different dynamics in each relationship as they pertained to urban identity and its ideals.

For Mylasa, these are the sanctuaries of Zeus Labraundos, located roughly 14 kilometers to the north, and the Karian god Sinuri, some 15 kilometers to the east. Labraunda had been promoted as the central Karian cult by the Hekatomnids, satraps of the Achaemenid empire in the mid-fourth century, who simultaneously turned it into a regional shrine and dynastic sacred center. In the later third century, the shrine and estates were controlled by Mylasa and Zeus Labraundos had become one of its main state cults. The sanctuary of Sinuri had also received patronage from the Hekatomnids. It appears to have been independent until sometime in the third century, when it noticeably fell within the jurisdiction of Mylasa. Administered by a sub-community of the polis, its decrees nonetheless reveal the impact of the polis at this sanctuary, near the border with Stratonikeia, in the overall integration of civic territory.

Stratonikeia was founded at a site roughly in between its two main sanctuaries: the shrine of Hekate at Lagina was some 8 kilometers to the north (via the ancient route between the mountains), while that of Zeus at Panamara was some 10 kilometers to the south. The sanctuary of Hekate at Lagina initially belonged to nearby Koranza, a polis in its own right. In the early second

282 Bilde and Lawall (2014). I am indebted to Pia Bilde† for her hospitality in allowing me to attend the workshop. 


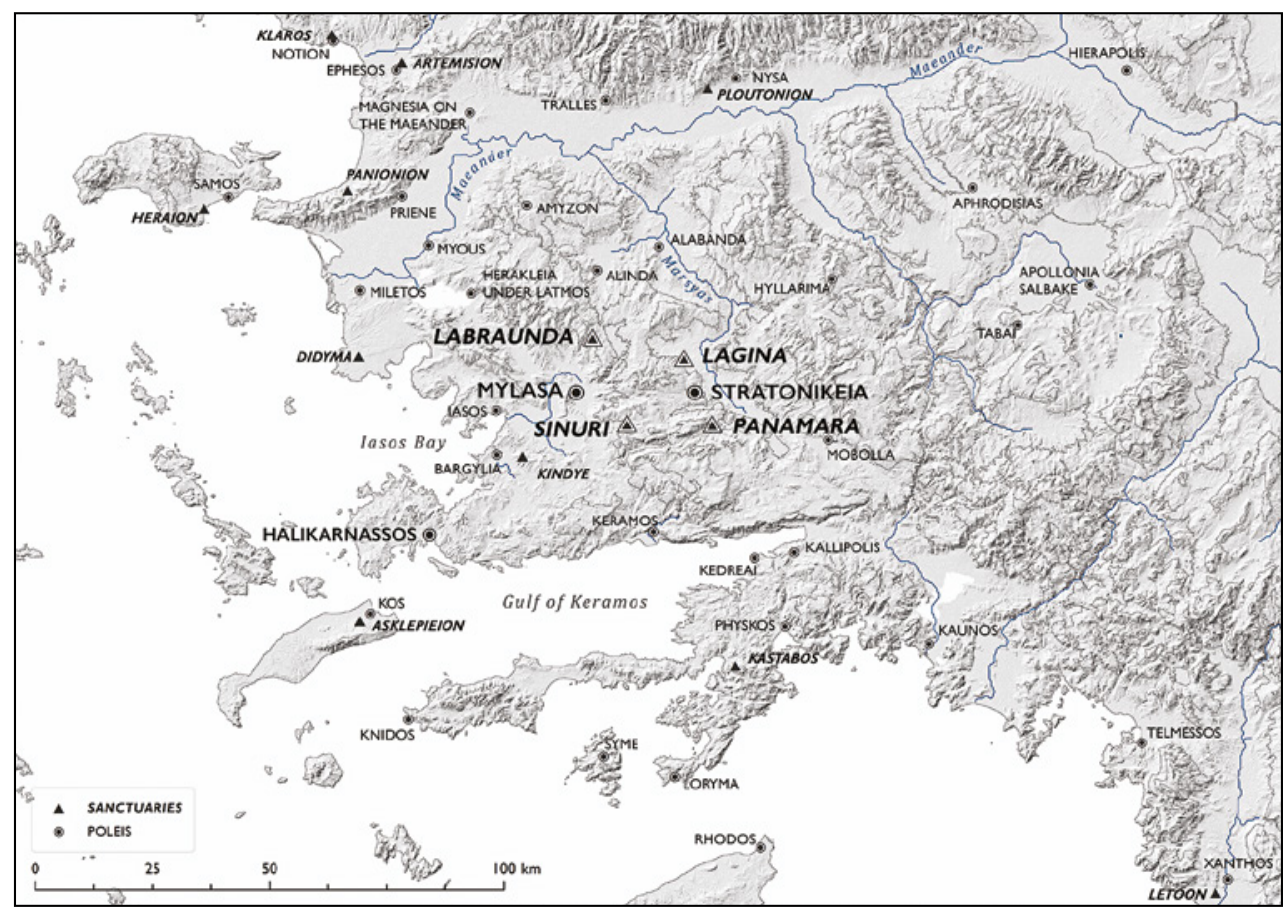

FIGURE 2.1 Map of southwest Asia Minor showing the locations of the case studies

century, if not before, Koranza became a deme of Stratonikeia while Hekate was promoted to patron goddess of the new city. The sanctuary of Zeus Karios at Panamara was initially a regional hilltop shrine administered by a distinct community; in the course of the second century it was entirely taken over by Stratonikeia; the polis now had both Zeus and Hekate as its patron gods.

These sanctuaries were also located in geographical locations that may well represent the physical boundaries of the civic territory, thus providing potential insights for a 'frontier' role, and whether the shrines fulfilled this function. Both cities, however, were also clearly composite entities, being socially and physically built up through processes akin to synoikism, where local communities were merged or even relocated to enhance the citizen population. Mylasa's early history is shadowy, but it appears to have been an agglomeration of the surrounding communities clustered together as a polis under the Hekatomnid satraps in the fourth century вс. ${ }^{283}$ Stratonikeia, on the other hand, was

283 Strabo 14.2.23 speaks of Mylasa as 'a mere village in ancient times'; on the presumed synoikism, see Rumscheid (2010), 97-98, and below in Chapter 3. 
clearly a Macedonian foundation, founded by the Seleukids probably as an outpost in Ptolemaic-oriented southern Karia. Local communities were, however, involved as at some point the surrounding villages had been absorbed as demes, although it is unclear exactly when this process took place or at whose behest. $^{284}$ Both cities demonstrate territorial ambitions and an aggressive expansionist policy. The fact that they were neighbors and for a time perhaps even rivals invites close scrutiny of their mutual borders as pressure zones with great potential for border conflict. ${ }^{285}$ Finally, three of the four sanctuaries have been excavated and published, albeit in varying degrees of completion. ${ }^{286}$ The fourth sanctuary, that of Zeus at Panamara, has yielded an epigraphic record that exceeds by far all of the others, even though the site awaits systematic excavation. It should be noted that as Stratonikeia developed in the Roman period, the epigraphic record at both sanctuaries grew immensely; several inscriptions from this period will be included in this present study as they articulate developments that initiated in the Hellenistic period.

284 Strabo 14.2.25 mentions Stratonikeia as 'a settlement of Macedonians'. On the villagedemes, see Şahin (1976), Debord (2001a), and van Bremen (2000), discussed below in Chapter 5 .

285 At least one border conflict is known between the two poleis, in I.Mylasa 134, discussed in Ager (1996), 101; see also Reger (2010).

286 Labraunda was excavated by the Swedish starting in 1948 and later under the direction of Pontus Hellström and Lars Karlson; currently under Olivier Henry and the Institute français d'études anatoliennes (IFEA). Labraunda has been extensively published, see labraunda.org. Lagina is one of the oldest Turkish excavations, and was until recently directed by Prof. dr. Ahmet Tirpan, now by Prof. dr. Bilal Söğüt, who also directs the excavations of Stratonikeia. Reports appear regularly in the Kazı Sonucları Toplantası. Sinuri was excavated by the French in the 193os, Devambez (1959). Louis Robert published the inscriptions, I.Sinuri. Panamara remains to be excavated although the inscriptions were published by Mehmet Çetin Şahin in the first volume of I.Stratonikeia. 